\title{
A Practical and Contemporary Model of Depression for Our Times-A Timeless Existential Clinician's Perspective
}

\author{
Sebastian Salicru \\ PTS Psychology, Canberra, Australia \\ Email: s@pts.net.au
}

How to cite this paper: Salicru, S. (2021). A Practical and Contemporary Model of Depression for Our Times-A Timeless Existential Clinician's Perspective. Open Journal of Depression, 10, 54-89. https://doi.org/10.4236/ojd.2021.102005

Received: February 28, 2021

Accepted: May 15, 2021

Published: May 18, 2021

Copyright $\odot 2021$ by author(s) and Scientific Research Publishing Inc. This work is licensed under the Creative Commons Attribution International License (CC BY 4.0).

http://creativecommons.org/licenses/by/4.0/

\begin{abstract}
Problem: Depression is spreading rapidly worldwide. It has been forecasted to become the leading cause of disability worldwide by 2030 , despite significant efforts and investments made to treat it. This menace has been exacerbated by the current COVID-19 pandemic which has triggered psychological distress and a surge in experiences of emptiness, sadness, and loss of meaning in life. Meaninglessness is one of the biggest threats of our times and is associated with depression and suicide. Gap: Existential psychotherapy has been neglected by researchers and remains misunderstood by the new generation of clinicians as an integrative approach to the prevention and treatment of depression, despite being one of the longest-established forms of psychotherapy. Objective: To address the above gap, recommendations, and emerging risks. Methodology: Review of theoretical and empirical findings, and autoethnography taking a scientist-practitioner stance. Results: A comprehensive, practical, integrated, flexible, and evidence-based model for the prevention and treatment of depression, and other internalizing disorders. Utility: This model will be of interest to researchers, practitioners, students of psychology, and the wider public. Conclusion/Recommendations: The model can be used to promote preventative factors in youth development, develop protective factors in high-risk populations with vulnerability to depression, and treat individuals experiencing depression or other internalizing disorders.
\end{abstract}

\section{Keywords}

Depression, Existential, Humanistic, Experiential Therapies, Psychotherapy Integration, Meaning, Purpose, Authenticity, Freedom, Responsibility 


\section{Introduction}

Depression is “affecting over 300 million people worldwide" (Zghoul et al., 2019: p. 95). Depressive disorders rise sharply after puberty (Lewinsohn et al., 2000), affecting $1 \%$ to $6 \%$ of adolescences each year worldwide (Thapar et al., 2010), and are usually associated with the onset of secondary disorders, impairment in social and occupational functioning, substance use disorders, and increase in suicidality (Hetrick et al., 2008). In fact, depression has reached epidemic proportions for children, teenagers and adults in modern life (Bulut, 2019). It has become "a major public health issue and is projected to become the leading cause of disability worldwide by 2030." (Ebert \& Cuijpers, 2018: p. 1).

Sadly, despite significant efforts and investments made to treat depression, mostly using pharmacological and psychosocial interventions, recent epidemiological research indicates that the prevalence of depression has not declined in recent decades (Ormel et al., 2020). This is due to the fact that such efforts have mostly focused on the treatment rather than prevention of depression, the quality deficiencies in existing treatments, and the overestimation of their effectiveness (McLaughlin, 2011). Improving this precarious state of affairs requires more timely and high-quality interventions, more judicious prescription of antidepressants, the consideration of psychological alternatives, offering more psychosocial treatment in primary care, and embedding more socially structured interventions (Ormel et al., 2020).

\subsection{The COVID-19 Pandemic, Meaningless, and Existential Approaches}

Tackling depression today matters more than ever before because the current situation has been aggravated by the existing COVID-19 pandemic, which "is associated with distress, anxiety, fear of contagion, depression and insomnia in the general population and among healthcare professionals (Sher, 2020: p. 707). Recent meta-analytic research indicates that about one in three adults among the general population had anxiety or depression since the pandemic started (Luo et al., 2020; Wang et al., 2020). Restrictive life measures and uncertainty about the future is making individuals vulnerable to feelings of helplessness and hopelessness, along with the corresponding increased risk of depression, anxiety, and related suicides worldwide (Pinto et al., 2020).

This recent outbreak has triggered a surge in experiences of emptiness, sadness, and loss of meaning in life (De Jong et al., 2020). Meaninglessness relates to a pervasive sense of the absence of purpose, significance and direction, with a tendency to reject meaning and higher-order explanations (Twenge et al., 2003). Underlying most suicide attempts is a failure to create meaning (Rogers, 2001). Not surprisingly, it has been suggested that suicide rates will rise and are likely to become a greater concern (Gunnell et al., 2020; Reger et al., 2020). This is in line with previous research that identified meaninglessness as one of the biggest threats of our times, and a possible symptom of depression (Vanhooren, 2019). 
Individuals who experience depression report lower levels of meaning (Volkert et al., 2014) and feelings of meaninglessness are associated with depression (American Psychiatric Association, 2013). Conversely, "people high in meaning in life tend to have better mental health than those low in meaning in life within the context of COVID-19" (Arslan et al., 2020: p. 1). Therefore, existential approaches have re-emerged and been proposed as critical protective factors and coping strategies to deal with the current global mental health crisis, and as an opportunity for growth (Joseph et al., 2020). Castiglioni and Gaj (2020), for example, propose the reconstruction of meaning-making processes as the means to normalize current distressing experiences due to the pandemic. In a more general way, Schippers and Ziegler (2019) propose life crafting as a way for individuals to find purpose and meaning in life, improve their adaptive coping, and ability to take control of their lives. Meaning acts as "a buffer against the effects of stress on well-being" (Mascaro \& Rosen, 2006: p. 183), and is a strong protective and preventive factor against depression and suicidal tendencies. Regrettably, "today's generation of young clinicians appear unfamiliar with how to incorporate existential concepts when treating adolescents experiencing internalizing symptoms" (Shumaker, 2012: p. 375) with other contemporary validated treatments (e.g. CBT, IPT).

\subsection{Adolescence and Young Adult Development}

In addition to the above, the current context presents unique and increasing challenges for adolescence and young adults in the development of their identity, and finding meaning and purpose in life. How adolescents formulate their identity has a critical impact on the rest of their lives. Ineffective coping makes them emotionally and behaviorally vulnerable. The development of a clear and positive identity facilitates the effective activation and use of their individual resources, and their development (Tsang et al., 2012). Similarly, establishing meaning and purpose in life contributes to positive youth development (Scales \& Leffert, 2004), predicts a sense of direction, enhanced physical and mental health, and more satisfying lives (Diener et al., 2012; Hill \& Turiano, 2014).

In this paper, I address the above-mentioned gaps, recommendations, and emerging risks by drawing on the rich and timeless legacy of existential, humanistic, experiential and integrative psychotherapies. To this end, I offer a contemporary, practical, and integrated model for the prevention and treatment of depression to pave the way forward. This model can serve as protective factor to inoculate people against the negative consequences the present and insidious pandemic is having on people's mental health. The model can be easily integrated into other psychological frameworks and therapeutic modalities. Thus, it will be of particular interest to psychotherapists and other mental health professionals working with individuals experiencing depression and other internalizing disorders.

The paper is structured into ten sections. First, the methodology used is out- 
lined. Second, a narrative review that synthesizes the theoretical background underpinning the model is provided. Third, assumptions and defining principles are clarified. Next, available research and evidence-based practices are highlighted. Further, the key constructs of the model are explained and its praxis is illustrated. Subsequently, the operationalization of constructs and psychometric measures are delineated. The limitations of the paper are laid out next, followed by conclusion and recommendations. The novelty of the paper entails broadening the scope of prevailing thinking, and linking theories and integrating relevant practices while providing multi-level insights for a better understanding of the prevention, assessment, diagnosis, and treatment of depression in our times.

\section{Methodology}

This qualitative paper draws on the extant literature, including both theoretical and empirical findings, takes a scientist-practitioner stance (Blair, 2010), and uses practitioner autoethnography (Kracen \& Bairdb, 2017; Liggins et al., 2013) which-like other narrative approaches—has already been used in counselling and psychotherapy research (Baumeister \& Newman, 1994; Etherington, 2001; House, 2007; Kirkman, 1999; Siddique, 2011; Smith, 2004). According to Blair (2010), "the scientist-practitioner model remains the most helpful model for counselling psychology" (p. 19) due to its high training standards and professionalism.

\section{Literature Review and Theoretical Background: Existential-Humanistic-Experiential-Integrative-Narrative Psychotherapies}

The exact etiology of depression is unknown. Hence, multiple explanatory theories and models (medical, genetic, and biopsychosocial) have been proposed to understand, prevent, and treat it. Nonetheless, depression is known to be more of a social problem than a medical disease (Yapko, 2009), multifaceted, and with social and psychological factors playing a more notable role (Stansfeld \& Rasul, 2007). This paper draws on the existential tradition which differs significantly from popular approaches in the conceptualization, assessment, diagnosis, and treatment of depression. "Despite being one of the oldest and most widespread forms of therapeutic practice, existential psychotherapy is, perhaps, one of the least well understood" (Cooper, 2008: p. 237). Existential therapies view depression as an experience resulting from encountering and confronting some of the most painful, harsh or challenging facts of life (e.g. adversity, suffering, loss, change, disappointment), which can result in despair, meaninglessness, and loss of purpose. From an existential perspective, being depressed means being stuck in the present by holding onto the past, and being unable to connect with the future (e.g. people, relationships, projects, possibilities).

"Existential psychotherapy is one of the longest-established forms of psychotherapy, dating back to the 1920s" (Correia et al., 2016: p. 5). Existential psy- 
chotherapies (EPs) encompass a range of psychological interventions by and large informed by phenomenology (as its epistemology) and existential philosophers-prominently, Heidegger, Sartre, Buber, Tillich, Kierkegaard, and Nietzsche (Cooper, 2012; Craig et al., 2016). Existentialism underscores the existence of the individual person as a free and responsible agent determining their own development through acts of will and is concerned with the quality of existence of individuals (Bugental, 1965). According to Yalom (1980), "existential psychotherapy is a dynamic approach to therapy which focuses on concerns that are rooted in an individual's existence" (p. 5). Szasz (2005) claims that EP "aims at enhancing self-knowledge in the client and allows them to be the authors of their own lives" (p. 127). "There is really no one existential therapy" (Basescu, 1963: p. 588), but rather multiple overlapping formats or unique expressions (Spinelli, 2007) of EPs. Namely, existential and humanistic (Bugental, 1965; Frankl, 1955; Laing, 1967; May, 1969; Yalom, 1991), meaning-centered (Wong, 2010, 2011), experiential (Greenberg \& Johnson, 1988), existential-integrative (Schneider, 2016), and existential-narrative (Richert, 2002, 2010) therapies.

Humanistic psychotherapy is based on humanistic psychology. Recognised founders of this movement include Rollo May, Gordon Allport, Abraham Maslow, Carl Rogers, and James Bugental (Krug, 2009). Rogers' seminal work in the early 1940s, as part of the "Third Force" in psychology (Bugental, 1965), progressively spawned "non-directive", "client-centered", later re-named "person-centered" psychotherapies (Rogers, 1942, 1951, 1961, 1980), and provided the foundation for a repertoire of therapies under the umbrella of humanistic psychotherapies (HPs). They emphasized working with clients' emotions and frame of reference, relational involvement and depth, making effective use of the self, focus on the self-concept, cultivating presence, and assisting clients to take responsibility by generating and enacting choices (Cain, 2007). HPs have now been impacting psychotherapy for over 65 years (Cain, 2010), and progressively have been grouped under the umbrella of so-called "experiential" psychotherapies (Greenberg et al., 1998).

Experiential psychotherapies (Mahrer, 1996, 2011) are an empirically derived approach aiming at transformation by attempting to reconsider what occurs in the client's world moment-by-moment via experiential listening. That is, "listening to the not yet fully articulated felt sense from which a speaker is talking" (Friedman, 2005: p. 217). Experiential psychotherapies also place a strong focus on emotions, and use action methods such as chair-work (Bell et al., 2020; Pos \& Greenberg, 2012) or empty-chair dialogue (Perls, 1969), or role reversal and sculpting, as used in psychodrama (Moreno, 1977).

Existential and humanistic approaches are often integrated into a unified approach, referred to as the humanistic-experiential psychotherapies (HEPs), or the E-H approach, as both perspectives are phenomenological in their orientation. The E-H approach is considered more experiential and pragmatic because is concerned with the most meaningful aspects of everyday life (Correia et al., 
2016) by paying particular attention to the essential themes of human existence, such as freedom, choice, responsibility, meaning, and finitude (Yalom, 1980). Despite the convergence between EPs and HPs, it is worthwhile highlighting some key distinctions. In short, search for meaning, via client responsibility and freedom, are major themes of EPs. Search for self, through acceptance and growth, is key to HPs. For a comprehensive comparison between both, refer to Winston (2015).

Meaning-centered psychotherapies (MCP) or meaning-centered counseling (MCC; Wong, 2010, 2011) are grounded in Frankl's (1969) Logotherapy (meaning therapy or therapy through meaning), which is designed to enhance individuals' meaning and quality of life. Logotherapy assumes that change happens when clients are able to accept or own their discomfort, instead of trying to avoid or eliminate it or attempting to change their milieu in unhealthy ways (Frankl, 1955). Along with Logotherapy's concept of tragic optimism, MCPs integrate meaning as a core construct. Person-centered therapy (PCT), emotion-focused therapy (EFT), Gestalt, and psychodrama approaches are also considered HEPs (Elliott et al., 2013).

Psychotherapy integration has become an influential movement within the practice of psychotherapy. According to Castonguay and Goldfried (1994), psychotherapy integration is a conceptual and clinical approach, "which is not only an effort to integrate diverse models and techniques but also an attempt to better understand and improve psychotherapy by considering the perspective of different approaches" (p. 160). This includes how better to deal with the complex processes of change and the factors that facilitate such change (Castonguay et al., 2003). Hence, the goal of the integration movement is to gain a better understanding and improve psychotherapy by merging distinct models and techniques beyond the boundaries of traditional single-school orientations (Arkowitz, 1992). Existential-integrative (EI) therapy was developed by Schneider (2016) based on the existential humanistic work of May (1958, 1981), Bugental (1976, 1987), and Yalom (1980). A good example of integrating existential and cognitive traditions is illustrated in the cognitive model of emotional processing proposed by Leahy (2002). In the model, the author utilizes "a more existential construct" (p. 182) of higher values, which is derived from Frankl's (1959) work.

Narrative therapy (NT) is a form of psychotherapy rooted in constructionism and assumes our lives are shaped by our stories, which produce meaning for our lives (White \& Epston, 1990). NT aims to assist clients by identifying their values and associated skills, engaging in re-storying their narratives, re-considering, re-appreciating, and re-authoring their preferred lives and relationships (Epston \& White, 1992). To this end, the clinician takes a collaborative, co-authoring, and consultative stance to assist clients to view themselves as separate from their problems by externalizing them (White, 1995). As Rosen (1996: p. 24) puts it, "the task of therapy is to assist clients in revising their old stories and in con- 
structing new ones that have more relevance and meaning for their current and future lives". To achieve this, NT uses metaphor, positioning (externalization), personal agency, subordinate story development (repositioning), intentionality, identity proclamation, and deconstruction (societal and cultural) principles (Stillman, 2016).

\section{Research on Humanistic Psychotherapies}

A sound cumulative quantitative and qualitative body of research demonstrates the effectiveness of humanistic psychotherapies over the last 70 years. This includes case studies, efficacy and effectiveness research, change-process research, and randomized controlled trials thus, offering adequate well-established evidence-based practice (Cain, 2002, 2010, 2016). A recent meta-analytical review conducted by Elliott et al. (2021, in press), which includes 91 studies published between 2009 and 2018 on the effectiveness/efficacy of HEPs, reveals that: they are associated with large pre-post client change; in controlled studies, clients in HEPs exhibit large gains relative to those who did not receive therapy; in comparative outcome studies, HEPs are generally statistically and clinically equivalent in effectiveness when compared to other psychotherapies.

\section{Evidence-Based Practice}

The model presented in this paper uses three pillars common to EPs, as identified by Hoffman et al. (2015). These three pillars are: 1) relatedness or relational focus; 2) emphasis on working with emotions and experience; and 3) meaningcentered approach. They have a strong foundation in empirical research, clinical competencies, and can be adapted to individual and cultural differences. As such, they are at the core of Evidence-Based Practice in Psychology (EBPP), as developed by the American Psychological Association, Presidential Task Force on Evidence-Based Practice (APA, 2006).

\section{Common Factors Theory}

EPs and humanism make use of common factors (CF) in psychotherapy (Wampold, 2012). CF theory (Frank \& Frank, 1993) offers a coherent scientific explanation of how people change during the therapeutic process. That is, the focus is placed on common factors both process and content variables (e.g. the therapeutic alliance, empathy, expectations, cultural adaptation, and therapist differences), or successful mechanisms of change that cut across different orientations (Grencavage \& Norcross, 1990) and that are present in all or most therapies regardless of their modality (Wampold, 2012). These CFs are more than just a set of individual elements common to therapies. They "collectively shape a theoretical model about the mechanisms of change in psychotherapy" (Wampold, 2015: p. 270). The present model is based on evidence-based treatment principles and $\mathrm{CF}$, rather than using prescribed change strategies or techniques, or using manualized treatments. 


\section{Assumptions and Defining Principles}

In this section, I outline the three key assumptions, defining principles, or what Spinelli (2007) calls "universal structures" (p. 7) of EPs, which are grounded on existential phenomenology (Buber, 1970; Heidegger, 1962; Husserl, 1965; Sartre, 1973).

\subsection{Relatedness}

Relatedness, inter-relation, or dialogical realms of encounter (Spinelli, 2006) is central to the therapeutic relationship that emerges between client and psychotherapist. In this type of encounter, clients can freely express and explore their currently-lived experience. This includes both limitations and possibilities of being in the world, as well as finding new means to reconstruct their ways of being.

\subsection{Existential Uncertainty}

Existential uncertainty is a direct consequence of relatedness in that it exposes inevitable and inescapable uncertainty, or lack of completeness, as opposed to certainty. It is a reminder to psychotherapists that they are not in charge of the therapeutic encounter and that they must be willing to accept uncertain outcomes (Spinelli, 2007). I would say this principle relates to the paradoxical requirement, for both client and therapist, of having to surrender their needs to have control of both the therapeutic process and outcomes.

\subsection{Existential Anxiety}

This principle reflects the point of view that anxiety is inevitable and universal (a given) to the human existence that permeates every expression of existence. It also acknowledges that denying or avoiding life or being (the experiential consequences of relatedness and uncertainty), will manifest symptoms and disorders (Spinelli, 2007).

\section{Stances and Practices}

In line with EHPs, this model views mental distress or psychological problems as the result of the inability to make meaningful, authentic, and self-directed choices on how to live. Hence, interventions are aimed at increasing client self-awareness, self-understanding, and deliberate action.

\subsection{Pragmatism}

Pragmatism is about placing the focus of psychotherapy on facilitating clients' decisions, choices, self-commitment, and concrete action. EHPs are pragmatic in nature because they attempt to connect the individual with reality (van Deurzen, 2012). This is achieved by helping clients to understand that knowing and being themselves are inseparable from their agency, which is best observed and experienced through their enactments in the world. Pragmatism means that clients are only able to move towards realizing their goals, potential and fulfillment through 
self-assertive living. This requires authenticity, which emerges gradually through subtle practice (Schoeller, 2020). I elaborate more on authenticity later.

\subsection{Fluidity and Integration}

The E-H approach is also fluid and integrative as it can be adapted to individual and cultural differences and easily integrated with other psychotherapeutic models (Schneider, 2016; Wampold, 2008). Clearly, the principles outlined previously are compatible with most approaches to psychotherapy. Not surprisingly, psychoanalysts like Otto Rank became one of the first existential therapists, who later influenced Rollo May, and alongside Viktor Frankl pioneered the existential psychology movement. This convergence also explains why many other psychotherapists were influenced by the phenomenological tradition and generated alternative models of psychotherapy due to increasing interest in existential-integrative (EI) therapies (Schneider \& May, 1995). Five examples of psychotherapies that were inspired by the phenomenological principle of attending to what is actually happening for the client include: Gestalt Psychotherapy (Perls et al., 1951); Client-centred Therapy (Rogers, 1951); Logotherapy (Frankl, 1972); Greenberg's (2011) Emotion-Focused Therapy (EFT); and Wong's (2010, 2011) Meaning-Centered Therapy (MCT) - which is based on Logotherapy. As noted by Mennin (2006), advances in psychological treatment have now recognized the convergence of different theoretical orientations towards psychotherapy of integration.

\subsection{Experiential Focus}

The experiential focus stance entails setting conditions that are immediate (happen in the "here-and-now"), kinesthetic (multi-sensory), affective (emotional), and profound (Schneider, 2016). Setting such conditions requires the following seven inter-related practices: presence; immediacy; use of self and self-disclosure; invoking the real; confronting resistance; working with emotions; and the discovery of meaning and awe.

\subsubsection{Presence}

“Therapeutic presence involves bringing one's whole self into the encounter with the client, being completely in the moment on a multiplicity of levels, physically, emotionally, cognitively and spiritually" (Geller \& Greenberg, 2002: p. 82), and "is one of the most therapeutic gifts a therapist can offer a client" (p. 72). According to May (1983), "Presence is not to be confused with a sentimental attitude toward the patient but depends firmly and consistently on how the therapist conceives of human being" (p. 158). In my experience, among other things, presence is what the therapist, without using direct self-disclosure, conveys to clients that-perhaps or very likely-the psychotherapist has also experienced what they are experiencing now. From this stance, psychotherapy is a fluid and creative process guided by intuition. As noted by Carson and Becker (2004), "Creativity is paramount to the therapeutic process" (p. 111), and the intuitive 
process is the essence of the therapeutic technique (Gendlin, 1996). Being creative enables the articulation of tacit (experiential) knowing in words or symbols, as well as revising those later (Bohart, 1999). Psychotherapists who consider their practices (methods and decisions) exclusively as the result of conscious reasoning are misguided (Welling, 2005). According to Schneider (2016), presence guides the therapeutic process in harmony with the client's desire and capacity for change, and to the degree the therapist is able to be present and sense how best to meet the client. It works like a mirror that illuminates and holds that which is tangibly and significantly occurring in the moment for the client and between client and therapist. Geller and Greenberg (2002) offer a comprehensive model of therapist presence that comprises three clusters: (1) preparing the ground for presence; (2) the process of presence; and (3) experiencing presence. Given that presence evokes and brings forth what is really going within the client-therapist relationship during the process of psychotherapy, it is inseparable from immediacy.

\subsubsection{Immediacy}

A salient contribution of the E-H method is the "here-and-now" processes that emerge in the therapeutic encounter-the here of the psychotherapy room and the now of the immediate moment (Yalom, 1980). Immediacy entails paying attention to, discussing, and processing what happens in real-time (here-and-now) within the client-therapist relationship (Kasper et al., 2008). Interpersonal theorists use the term "metacommunication", referring to talking in the here-and-now about the here-and-now, for this therapeutic intervention (Kiesler, 1988), and suggest that clients re-enact their interpersonal conflicts that brought them into psychotherapy in the first place with the therapist (Cashdan, 1988; Yalom, 2002). The way I put it is that the process of psychotherapy becomes a microcosm for clients to experiment with their possibilities in the real world. Doing so makes the therapist a critical instrument of the therapeutic process, and has implications related to the therapist's use of self-disclosure.

\subsubsection{Use of Self and Self-Disclosure}

The use of self, or the self as an instrument, is central to HEPs more than any other type of psychotherapy (Hoffman et al., 2015), as it assumes that such interventions demonstrate therapists' positive regard and genuineness for clients, and has been recognized as the most important factor in building the therapeutic alliance by prominent psychotherapists (Andolfi et al., 1993; Lum, 2002; Satir et al., 1991). Therapist self-disclosure (TSD) is arguably the most practiced use of self. It occurs when therapists disclose to their clients, personal information about themselves (Hill \& Knox, 2001). Immediate disclosure entails therapists sharing thoughts, feelings, or opinions about the client and the therapeutic process. Nonimmediate disclosure occurs when therapists share experiences external to the therapeutic process (e.g. biographical details, coping strategies, or personal insights (Ziv-Beiman \& Shahar, 2016). Other authors (Scheiner \& Sleater, 2020), 
distinguish between overt self-disclosure, inadvertent self-disclosure, and unconscious self-disclosure.

Despite being a controversial topic and traditionally considered a taboo, when used wisely, TSD "has potential to promote positive change and to assist in the development of a good therapeutic alliance" (Bloomgarden \& Mennuti, 2009: p. 3 ), and "properly used, can be a significant contributor to successful psychotherapy" (Stricker, 2003: p. 263). According to Baldwin (2013), TSD lacks the attention it deserves and asserts that who the therapist is, and what is shared during therapy, is as critical as the therapeutic modality used. Dewan (2006) views TSD as the hallmark of skilful practice. Intentional TSD requires high levels of self-awareness, and highly tuned interpersonal skills (e.g. tact, sensitivity, timing, patience, and humility), which cannot be learned from a manual, and should be relative to the unique context and specific individual clients' needs (Geller, 2003). Consensus exists in that TSD should happen in the here and now, be spontaneous, should not take time that belongs to the client by promptly bringing the focus back to the client (Dewan, 2006; Henretty \& Levitt, 2010; Kiesler, 1988), and be exercised judiciously and in accordance with clients' readiness (Cooper, 2012; Yalom, 1980). I would add that TSD should always be done for the benefit of clients, with a deep sense of humility, and with an explanation to clients of the reason for disclosing, as well as considering asking for clients' permission before disclosing (e.g. "Would it be useful, if I share ...).

The power of TSD requires the integration of various therapeutic dimensions to both "strengthen the therapeutic relationship and advance diverse dimensions of therapeutic change" (Ziv-Beiman, 2013: p. 59). As in CBT and relational psychodynamics, E-H therapies use self-disclosure to achieve multiple goals, such as: strengthening the therapeutic alliance, normalizing clients' experiences; challenging negative interpretations of emotions and behavior; heightening motivation and positive expectations for change; increasing clients' self-acceptance and insight; or modeling and reinforcing desired behaviors (Goldfried et al., 2003).

Henretty and Levitt's (2010) research found that TSD is extremely common, with over $90 \%$ of practitioners reporting having disclosed information about themselves to their clients occasionally. Further, self-disclosure (vs. nondisclosure) had a positive effect on clients; clients had a stronger liking for therapists who self-disclosed; clients perceived therapists who self-disclosed as warmer; clients self-disclosed more to therapists who self-disclosed; and clients had a more positive response to therapist disclosures related to thoughts and feelings about the client compared to therapist self-disclosures about other therapy experiences.

\subsubsection{Invoking the Real}

Invoking the real, actual or palpable entails paying attention and appealing to the parts of the client that are attempting to emerge, although not necessary being seen or noticed, and inviting them to articulate that which is conspicuously significant to them (Schneider \& Krug, 2010; Schneider \& May, 1995). This 
process is facilitated by using queries related to clients' issues and concerns using a personal and topical focus (e.g. "What feels most important for you in this moment?"), topic expansion (e.g. "Could you tell me more about this?”), and elaboration of a specific experiential theme (e.g. "What else are you noticing right now?"). This is done with attention to the process, as much as the content, by using immediacy. For example, reflecting on a client's incongruence (e.g. "I hear the seriousness of your concerns, and yet you're smiling"), and body or energy shifts (e.g. "I notice you're glowing with excitement since we began to talk about your daughter").

\subsubsection{Confronting Resistance}

Confronting resistance or vivifying self-protection (Schneider, 2016) is a relational skill that therapists used to alert (reflect) clients when they diverge from, or suppress, emotionally painful material in order to protect themselves. This is done respectfully, with lightness and gentleness, and in a spirit of collaboration thus, encouraging clients to overcome their blocks, and being able to engage safely and honestly with their painful memories and/or emotions (Schneider \& Krug, 2010).

\subsubsection{Working with Emotions}

Emotions are central to all forms of psychotherapy, as one of the main reasons why clients come to therapy is to better understand and deal with their emotional struggles (Hoffman et al., 2015). Rather than attempting to change emotions, E-H approaches seek to change the way clients experience their emotions to create new meaning, as meaning making is generated through active reflection on emotions (Greenberg, 2011; Greenberg \& Pascual-Leone, 2006). In my experience of this work, this entails being able to access deep and hidden emotions that are embedded within the clients' narratives and metaphors, with a view to create new meaning and possibilities, and alternative stories that work as anchors of a transformative therapeutic process.

\subsubsection{Discovery of Meaning and Awe}

Discovery or re-discovery of meaning and awe is more a therapeutic outcome than a practice. It relates to the, often unexpected, benefits that clients experience beyond their specific therapy goals (e.g. the relief of symptoms). According to Schneider (2016), this includes their new relationship to life, with humility and a sense of wonder or adventure towards existence. This becomes a template for clients to live life at their maximal capacity. In my clinical practice, some clients report this discovery as a unique experience, such as a sense of calmness, composure, serenity or peace of mind for the first time in their lives when facing their old life problems and challenges. From time to time, they use the expression, "I'm in awe"! This declaration occurs as result of a violation of their own expectations, resulting in some kind of a transformational experience resulting from their psychotherapeutic work, which causes their consternation. 


\section{Key Constructs and Praxis}

In this section, I outline the key constructs of the model and how they can be applied in clinical practice.

\subsection{Meaning and Purpose}

Meaning-seeking is a unique privilege of humankind. Accordingly, our brains are organized for meaning-making, as a distinctly human activity that coordinates patterns of action (Emmons, 2003). Meaning in life is the need to perceive our lives, our suffering in particular, as making sense in serving some worthy purpose (Frankl, 1969). Having a meaningful life provides people with a special resilience that promotes sustained hope, and, like happiness, is one of those things that cannot be achieved directly (Frankl, 1959). The positive relationship between living a meaningful and purposeful life and psychological well-being is supported by extensive research (King et al., 2006; Kleftaras \& Psarra, 2012; Mascaro \& Rosen, 2005; Reker, 2005; Steger, 2012; Steger et al., 2006). Having more meaning in life is positively linked to work enjoyment (Bonebright et al., 2000), predicts life satisfaction and positive well-being (Zika \& Chamberlain, 1987), and happiness (Debats et al., 1993). Personal meaning is the "cognizance of order, coherence and purpose in one's existence, the pursuit and attainment of worthwhile goals, and an accompanying sense of fulfillment" (Reker \& Wong, 1988: p. 221).

Personal meaning relates to having a life purpose, sense of direction, order and a reason for existence, personal identity, and enhanced social consciousness (Reker et al., 1987). This perspective on depression is somewhat compatible with psychoanalytic thought and behaviorism. Existentialism, however, emphasizes that the lack of personal satisfaction with the quality of an individual's life constitutes a threat to self-esteem, the positive or negative disposition toward oneself and one's sense of worth or value or respect (Rosenberg, 1965), which in turn leads to a sense of personal alienation and loss of meaning (Klinger, 1977). Conversely, psychological distress is caused by deficits in meaning (Joshi et al., 2014) and meaning is inversely related to negative affect and depression across all age groups, with the magnitude of the relationship being greater at later stages of life (Steger et al., 2009a). Meaning in life has also been identified as a protective factor against adolescents' poor psychological health and risk behaviors (Brassai et al., 2011).

Existential meaning relates to how individuals seek coherence about their lives (Mascaro \& Rosen, 2005), explicitly make sense of their experiences, and are conscious of how they feel about their lives and lives' purpose (Steger et al., 2009b). More implicitly, according to Wong (1998), meaning in life is a multidimensional construct that comprises how people experience the following seven key domains of their lives: 1) achievement-the pursuit and attainment of significant life goals); 2) self-acceptance-the humble acceptance of one's limitations; 3) relationship—social adeptness; 4) intimacy—having emotionally close 
and loving relationships; 5) fair treatment-the perceived degree of justice in one's life; 6) spirituality-positive beliefs about and a relationship with the divine; and 7) self-transcendence-engagement in selfless pursuits that benefit others. Meaninglessness has been recognized as recurring and often neglected problem in modern society which, unresolved, is likely to lead to depression and other forms of distress and psychopathology (Klinger, 1977; Ruffin, 1984). Having less life meaning is associated with higher need for psychotherapy (Battista \& Almond, 1973), increased depression and anxiety (Debats et al., 1993), and suicidal ideation and substance abuse (Harlow et al., 1986).

The search for a meaningful life fulfills four distinct types of individuals' needs via four motivation patterns that guide them to attempt to make sense of their lives (Baumeister, 1991). The first need is that of having purpose. In essence, purpose relates to the fact that present actions draw meaning from their connection with future events. Hence, "the essence of meaning is connection" (Baumeister \& Vohs, 2002: p. 608). Meaning in life then is the result of our capacity to connect things, events, and relationships, which in turn affords us shared mental representations of the future. Without meaning, our behavior would be simply driven by impulse and instinct. Therefore, meaning provides intention and direction. From this perspective, as noted by Emmons (2003), and consistent with Frankl (1972), meaning in life has a goal attainment and motivational quality that enables the pursuit of significant life goals, which in turn leads to actions and the generation of positive life events and experiences of wellbeing. Not surprisingly, individuals who report high levels of meaning in life also report greater time and effort spent in pursuance of their goals in life (Vallerand, 2008). Meaning in life, therefore, counters the inherent sadness, hopelessness, and passivity of depression by generating and sustaining intrinsically motivated behavior (McKnight \& Kashdan, 2009). The second need is our need for having values which guide our conduct (e.g. sense of goodness or positivity to life), and guide and justify our choices of action. Values enable us to determine whether certain actions are right or wrong, acceptable or unacceptable. If we take action based on our values, we are confident and secure that we have done the right thing thus, lessening anxiety, guilt, regret, and/or other forms of dissonance or moral distress. The third need is for a sense of efficacy, the belief that one can make a difference, and self-efficacy, the belief in our capacity to organize and execute the necessary behaviors to manage situations and performance or complete tasks successfully. A life with purpose and values, but without self-efficacy would be futile. The fourth and final need is self-worth. Individuals seek reasons for believing that they are good and worthy.

Meaning-making or sense-making is the active process of revising or reappraising life events as an attempt to: search for new meaning in such experiences; attain mastery over these events - and more specifically over life in general; and restore self-esteem via self-enhanced evaluations (Taylor, 1983). Finding meaning therefore requires modifying attributions and perceptions of nega- 
tive life events through the process of changing life schemas, which in turn restore feelings of adequacy of our sense of purpose (Thompson \& Janigian, 1988). "Purpose is a central, self-organizing life aim that organizes and stimulates goals, manages behaviors, and provides a sense of meaning (McKnight \& Kashdan, 2009: p. 242).

The benefits of meaning-making include being able to establish a clear sense of identity and affirmation of self-worth (Baumeister \& Wilson, 1996) by rescripting one's life story (McAdams, 1996). "Purpose in life and personal growth are not contributors to, but in fact defining features of, positive mental health" (Ryff \& Singer, 1998: p. 216). Meaning-making is also linked to positive health outcomes (Pennebaker et al., 1988). Conversely, the lack of low or impoverished meaning-making is associated with multiple forms of cognitive and emotional distress, such as sadness and emotional dejection (Baumeister \& Vohs, 2002). This indicates that meaning in life is an important mediating variable in the psychopathology of internalizing and adjustment disorders (Marco et al., 2020). In clinical practice, I increasingly work with young depressed clients who, implicitly or explicitly, question the meaning of life and/or their life purpose. For such individuals meaning-making interventions offer a very practical approach to address their concerns.

\section{Meaning and Purpose}

As stated earlier in the introduction section, depression and has reached epidemic proportions in children, teenagers and adults in recent times. This includes serious psychological distress and suicide-related outcomes (suicidal ideation, plans, attempts, and deaths by suicide) among young adults (Twenge et al., 2019). Hence, more than ever before, depression constitutes an extremely serious public health issue which is projected to become the leading cause of disability worldwide by 2030 (Ebert \& Cuijpers, 2018). These research findings are consistent with my experience in clinical practice. It is not an exaggeration to say that generally young people present to psychotherapy with an implicit or explicit profound desire to find meaning and purpose in their lives. It is also short of inspiring, as well as fascinating, to realize how little encouragement is often needed to offer adolescences the hope they need by taking them on a journey in which setting their therapy goals and working towards achieving them, becomes their interim search for meaning and purpose in life.

Meaning-oriented psychotherapy is effective for the prevention of depression among young populations because searching for meaning is reported at higher rates during emerging adulthood and young adulthood (Steger et al., 2009a), and the development of purpose is critical during the formative period of adolescence (Damon et al., 2003). This has been long confirmed by identity theorists (Erikson, 1968; Loevinger, 1993). Moreover, existential meaning explains a significant variance in hope and depressive symptoms (Mascaro \& Rosen, 2005). Hope is a primary variable in the etiology of depression (Kwon, 2000; Whisman \& Kwon, 1993) which has repeatedly been found to have a strong inverse rela- 
tionship with depression (Snyder et al., 1996). Conversely, hopelessness has a strong effect on the variance in successful suicide (Beck et al., 1990). Hence, meaning not only acts as "a buffer against the effects of stress on well-being" (Mascaro \& Rosen, 2006: p. 183), but it is also a strong protective and preventive factor against suicidal tendencies.

\subsection{Authenticity}

Expressions such as "I need to find myself" or "I need to discover who I really am", are not uncommon in everyday life. Similarly, the theme of discovering “one's true self" has been popular in literature and the performing arts. Underpinning the notion of a true self is that individuals experience themselves as having both an external self and an inner core, essence, or authentic self, which is not necessarily reflected in the external world (Johnson et al., 2004).

In clinical practice, it is not uncommon to hear clients' expressions such as, "I sometimes feel that I'm wearing a mask". It seems as if people intuitively come to psychotherapy because they feel the need to eliminate or reduce the gap between their true and false self so, they can find out what is behind their mask. The metaphor of "self-discovery" traces back to Aristotelian eudaimonia, which predicates that "individuals have a responsibility to recognize and live in accordance with their daimon or true self" (Waterman, 1990: p. 39). "It is remarkable to think that the use of metaphors can have such a profound effect on the way we approach a question as fundamental as "Who am I?" (Schlegel et al., 2012: p. 990).

Authenticity has long been conceptualized by different philosophical schools (e.g. Aristotle, Descartes, Hume, Rousseau, Kierkegaard, Dostoevsky, Nietzsche, Heidegger, Camus, Sartre). According Sartre, for example, “Authenticity consists in having a true and lucid consciousness of the situation, in assuming the responsibilities and risks that it involves in accepting it in pride or humiliation, sometimes in horror or hate" (cited by Golomb, 1995: p. 12). Subsequently, building on these schools of thought, the authenticity concept has been adopted by multiple psychological movements, in particular, the existential and phenomenological (Medlock, 2012). Namely, humanistic (Maslow, 1968; Rogers, 1961), existential (May, 1983), clinical (Ehlers et al., 2000), counseling (Lopez \& Rice, 2006), developmental (Harter et al., 1996), evolutionary (Sedikides \& Skowronski, 1997), psychodynamic (Horney, 1951; Winnicott, 1965), social (Kernis \& Goldman, 2006), and more recently the positive psychology movement (Sheldon, 2004; Ryff \& Singer, 2008).

James (1890), for example, distinguished between the self as "Me" (the known self) and self as "I" (the knower self). In short, the "Me" relates to the self as the object of the experience or cognition (self as object). This includes the perceptions and multiple mental representations and descriptions that we have about ourselves, such as personal qualities, experiences, thoughts, and feelings. In other words, the "Me" that is being observed, as my narrative or story. The "I", on 
the other hand, relates to the self as the subject of experience (self as subject). That is, the causal agent, thinker or observer who does the thinking or observing, who is also responsible for self-awareness and self-knowledge. This distinction in self-referential awareness has re-emerged recently in neurocognitive science (Tagini \& Raffone, 2010), particularly in the context of experimental studies investigating the phenomenological self and consciousness (Woźniak, 2018). This is notwithstanding the fact that, as noted by Rafaeli et al. (2014), the monolithic conceptualization of the self has been rejected previously by various psychotherapeutic modalities (e.g. Gestalt, Object Relations, Self-Psychology, Psychodrama, Schema Therapy) by recognizing and adopting a multiplicity of the human self.

In clinical practice, mindfulness and mindfulness meditation are useful strategies to assist clients to develop this self-referential distinction. More specifically, this distinction enables them to become aware of the over-identification (or fusion) of their thoughts and feelings. During mindfulness meditation, clients learn to bring their attention to the present moment in a curious, non-judgmental, accepting way (Kabat-Zinn, 1990). This enables them to observe and notice-in a detached way-their current thoughts, feelings, and bodily sensations as something that happens to them, which are ephemeral and pass over time, and which are extrinsic to who they actually are. Thus, mindfulness mediation (and other types of meditation) prevents clients from identifying with their thoughts, feelings, or the stories they tell themselves. Once they are able to create a healthy space between themselves and their emotions, they learn they are not their emotions, but rather they have or experience emotions. As a result, they are able to respond to any given situation with intention and purpose, as opposed to being at the mercy of their thoughts and feelings. This affords them self-regulation and self-control (Friese et al., 2012).

The above practice invites clients to witness their most difficult emotions with curiosity, compassion, and acceptance, which is at the heart of Acceptance and Commitment Therapy (Hayes et al., 2006). Thus, clients learn that their emotions inform them about something about themselves and/or the situation they find themselves in. They also learn that difficult emotions can help them to anticipate pitfalls, and prepare them with more effective ways of coping during critical situations. Similarly, clients learn that because they are now prepared and able to contain their feelings and past experiences, they are ready to accept all parts of their existence without being terrified or crushed. Existentially speaking, they learn David's assertion that "Discomfort is the price of admission to a meaningful life" (Cited by Ward, 2019: p. 2).

Barnes (1959), from an existential perspective, asserts that humans become inauthentic when they lose themselves by pretending that they have no responsibility for their lives. From an object relations and developmental perspective, talking about the ego's distortion in terms of true and false self, Winnicott (1960) explains that "the False Self is represented by the whole organization of 
the polite and mannered social attitude..." (p. 143). He uses the term to describe the defensive mechanism infants are compelled to use to respond to inadequate mothering or failures in empathy, which forces them to relinquish or accommodate their own needs to satisfy the conscious and unconscious needs of the caregivers upon whom they are completely dependent. This is the beginning of the development of the early maladaptive schema of subjugation-the surrendering of control to the wishes of others while suppressing one's own needs and desires, which is a predictor of depression (Basile et al., 2018).

Maslow (1968), from a humanistic psychology perspective refers to "authentic" or "true" individuals as those who develop their true nature to fulfil their self-actualizing needs, find a meaning to life by becoming what's important to them thus realizing their full potential. Laing (1967) refers to the persona, mask or part being played and the person as the actual self. According to Rogers (1961), psychological disturbance occurs from the incongruence between individuals' real-self (their actual behavior) and their "ideal self" (who they would like to be). From his perspective, authenticity relates the congruence, alignment or consistency between the two. As clients become more real, congruent, and focused upon their real selves, they also become more integrated. At that point, the therapeutic work is completed.

The above notions are in line with Self-Discrepancy Theory (SDT), which explores how individuals compare their perceived or "actual self" to their "ideal/ ought self” or their internalized standards (Higgins et al., 1985). Inconsistencies between the two predict depression, sadness or melancholy (Phillips \& Silvia, 2010). Adolescents are particularly at risk of hiding their true self because adolescence is characterized by an increase in displays of false self-behavior as an attempt to deal with feelings that they may not good enough for others (Harter et al., 1997). This display of false self by putting up a façade, along with the suppression of true feelings and thoughts, leads to experiencing a lack of voice (Gilligan, 1993), low self-esteem, and depressive symptoms (Harter et al., 1996; Higgins, 1987; Higgins et al., 1985). Similarly, Self-Determination Theory (Deci \& Ryan, 2008) contends that authenticity entails self-regulation in ways that fulfill individuals' psychological needs (internal regulation or being authentic) for self-determination, competence and relatedness as opposed to self-regulation in order to meet the demands or expectations of others (external regulation or being authentic). As alluded to earlier, this form of denying one's core needs is the essence of the maladaptive schema, which has been found to predict depression (Basile et al., 2018).

Empirical research supports the proposition that, by serving a meaning-making function, the true self (authenticity) enhances life satisfaction, well-being, and optimal psychological functioning (Boyraz et al., 2014; McGregor \& Little, 1998; Schlegel et al., 2009). Knowing the true self predicts self-actualization, self-esteem, vitality, and active coping with adversity (Kernis \& Goldman, 2006; Lakey et al., 2008). Conversely, lack of authenticity causes distress and psychopathology, as it 
causes individuals to engage in unnatural and forced behavior, leaving them feeling devalued and unfulfilled (Leary, 2003).

In my extension of this work, the most common factors clients-young populations in particular-encounter in living authentically are: their desire to be popular at the expense of being themselves; finding it difficult to stand by what they believe in; being strongly influenced by the opinions of others; and feeling they need to do what others expect them to do; and usually ending up doing what others tell them to do. Invariably, over time, this leads to people feeling alienated from themselves and out of touch with their real selves, as if they don't know themselves very well. In turn, this makes them feel that they have no voice or sense of identity, and extremely vulnerable and disempowered. All in all, the perfect storm for experiencing depression, and turning to alcohol and drugs as the quickest and easiest way to cope. The therapeutic challenge for these youngsters is for them to learn that behaving authentically requires taking responsibility and courage, as their individual tendencies and desires may conflict with their peers and authority figures that have strong evaluative or controlling influence on them (Deci \& Ryan, 1995).

\subsection{Freedom, Responsibility, Choice, Agency, and Empowerment}

Firstly, I would like to clarify that, contrary to popular beliefs; EHPs acknowledge that human beings are not always free to choose. This notion is encapsulated in Heidegger's (1962) concept of "thrownness", denoting that all humans are "thrown into" being. Hence, our thrownness means that no human had the choice to come into existence. From an existential perspective, however, humans are responsible for the quality of their existence because they possess "finite freedom" (Tillich, 1952: p. 52), and in spite of how constricting the limitations may be, as humans we still carry the burden of full responsibility for our actions and decisions within such limitations. This freedom affords possibility through a range of alternatives for action at any given time and situation (Barnes, 1959). Possibly the best example of this is Frankl's (1959) autobiographical account of his imprisonment in a Nazi concentration camp where he chose to focus on inner freedom, the power of purpose, hope, responsibility, and the inspiration he found through the beauty of art and nature, to help him to endure and survive harrowing and agonizing experiences. According to Frankl (1967), "what man needs is not a tensionless state, but the striving and struggling for something worth longing and groping for" (p. 68). From a E-H perspective, depression is an outcome of individuals' responses to the difficulties of coping with freedom. This freedom entails taking responsibility for the choices people make to govern the quality of their lives. Responsibility is "the ability to respond" (Spinelli, 2007: p. 49). Alternatively, people can block the awareness of their freedom, and the resulting responsibility, through self-denial. The latter results in loss of self and personal alienation. Depression, then, is the ultimate outcome of failing to take action, as a way to avoid the recognition that we have choices, and therefore that 
we are responsible for the quality of our lives. From this perspective, depression is the ultimate indicator telling us we can no longer avoid the realization that life is unbearable without meaning or significance. Hence, Nietzsche's maximum, "He who has a why to live for can bear almost any how" (as cited in Frankl, 1959: p. 126).

As a result of the above, explains Schneider (2016), EPs are driven by two key implicit and ongoing questions: 1) How is the client currently living? and 2) How is the client willing/wanting to live? Hence, the main goal of EPs is to assist clients to increase their freedom by making choices, within the natural restriction (e.g. societal, cultural, environmental) or self-imposed limitations of their life or living. Choice relates the capacity to constrict and expand, as required by the client and situation demands. Clients' desire and capacity for change are key determinants of their choices.

In clinical practice, it is not uncommon to witness how clients sabotage themselves from becoming aware of their freedom and taking responsibility through self-denial in very subtle and insidious ways. This is illustrated through the following example. When asking clients how they coped with an unpleasant or adverse situation, they will often say, "I tried to think positively, but it didn't work". In such cases, upon further exploration, it becomes clear that "thinking positively" was used as an avoidance strategy. This happens because, when faced with negative situations, people mistake being positive (or denial) with being hopeful and optimistic. Presumably, this is the legacy of pop psychology or the positive thinking movement which promotes the intolerance of, and pathologizes, negative feelings. A phenomenon that has been labelled as "the tyranny of the positive attitude" (Held, 2002: p. 965). While attitudes of hope and optimism are future-oriented and desirable, facing adversity with clarity, acceptance, courage, and active problem solving by taking responsibility in order to create a better future is an absolute requirement for dealing effectively with adversity and building resilience. It is therefore unwise to use positive thinking (wishful thinking, more to the point here) at the expense of facing reality. Dealing with adversity affords clients the opportunity to transform their suffering through meaning making. As Frankl (1972) puts it, "suffering ceases to be suffering at the moment it finds a meaning" (p. 117).

Similarly, facing and dealing with adversity builds individuals' sense of personal agency-the "ability to make purposeful choices" (Samman \& Santos, 2009: p. 3), personal agency relates to the way in which clients view themselves as being relatively passive or active (Madill \& Doherty, 1994). It means that clients think and/or act differently than they did previously in similar situations (van Inwagen, 1983), and it is easy to detect (measure) during psychotherapy. A good example from clinical practice is the way in which a client responded when asked, "So, how was it for you telling your boss that you didn't like the way he was talking to you?". "I felt powerful. I felt proud of myself!" Clearly, in this case, personal agency and personal empowerment-“...developing a sense of self and 
individual confidence and capacity, and undoing the effects of internalised oppression" (Rowlands, 1995: p. 87), are equivalent. While the idea of heightening clients' agency in psychotherapy is relevant to most psychotherapeutic traditions, as well as an important indicator of positive psychological functioning (Williams \& Levitt, 2007), this construct is more relevant to the humanistic psychotherapy because of its emphasis on enabling clients to develop a capacity for self-direction through introspection and self-examination in a supportive environment (Rogers, 1951). Humanistic approaches emphasize experiential reflection, freedom, and responsibility. To this end, the humanistic stance entails setting conditions to assist clients to know themselves intimately, and to confront and deal with their real-life challenges so they can fulfill their aspirations and become more of who they aspire to become (Schneider \& Leitner, 2002).

\section{Operationalization of Constructs and Psychometric Measures}

No evidence-based model or framework would be complete without being able to operationalize its constructs, and have the measures to assess needs, monitor progress, and measure and evaluate outcomes. In this section, I present a selection of suitable, reliable, and valid psychometric measures to do so. The literature identifies over fifty instruments that could potentially be used to assess existential psychotherapeutic practices. Given the length limitations of this paper, I only present a selection of five measures in Table 1 below.

The Authenticity Scale (AS) is possibly the most useful measure to use in psychotherapy, as it is the only one grounded in psychotherapeutic theory, and was developed as a short outcome measure for clinical/counseling practice and research (Mørken, 2019). Not surprisingly, the three subscales of the AS have high face validity and acceptability with clients, and correlate with commonly used clinical outcome short measures such as the Depression Anxiety Stress Scales (DASS-21, Lovibond \& Lovibond, 1995).

Other related measures available in the literature and worthwhile mentioning include: The Life Regard Index (LRI; Debats et al., 1993); The Seeking of Noetic Goals (SONG; Crumbaugh, 1977); The Personal Meaning Profile (PMP; Wong, 1998); The Meaning in Life Measure (MLM; Morgan \& Farsides, 2009); The Existence Scale (ES; Längle et al., 2003); and The Life Engagement Test (LET; Scheier et al., 2006).

\section{Limitations}

This conceptual paper is limited to literature, prior empirical research, and lessons from the field. Despite this limitation, the paper is timely and relevant, synthesizes the extant literature and empirical findings, links theories and practices across models, provides multi-level insights, and broadens the scope of the prevailing thinking for a better understanding of the prevention, assessment, diagnosis, and treatment of depression in our times. 
Table 1. Selection of psychometric instruments to work with EPs.

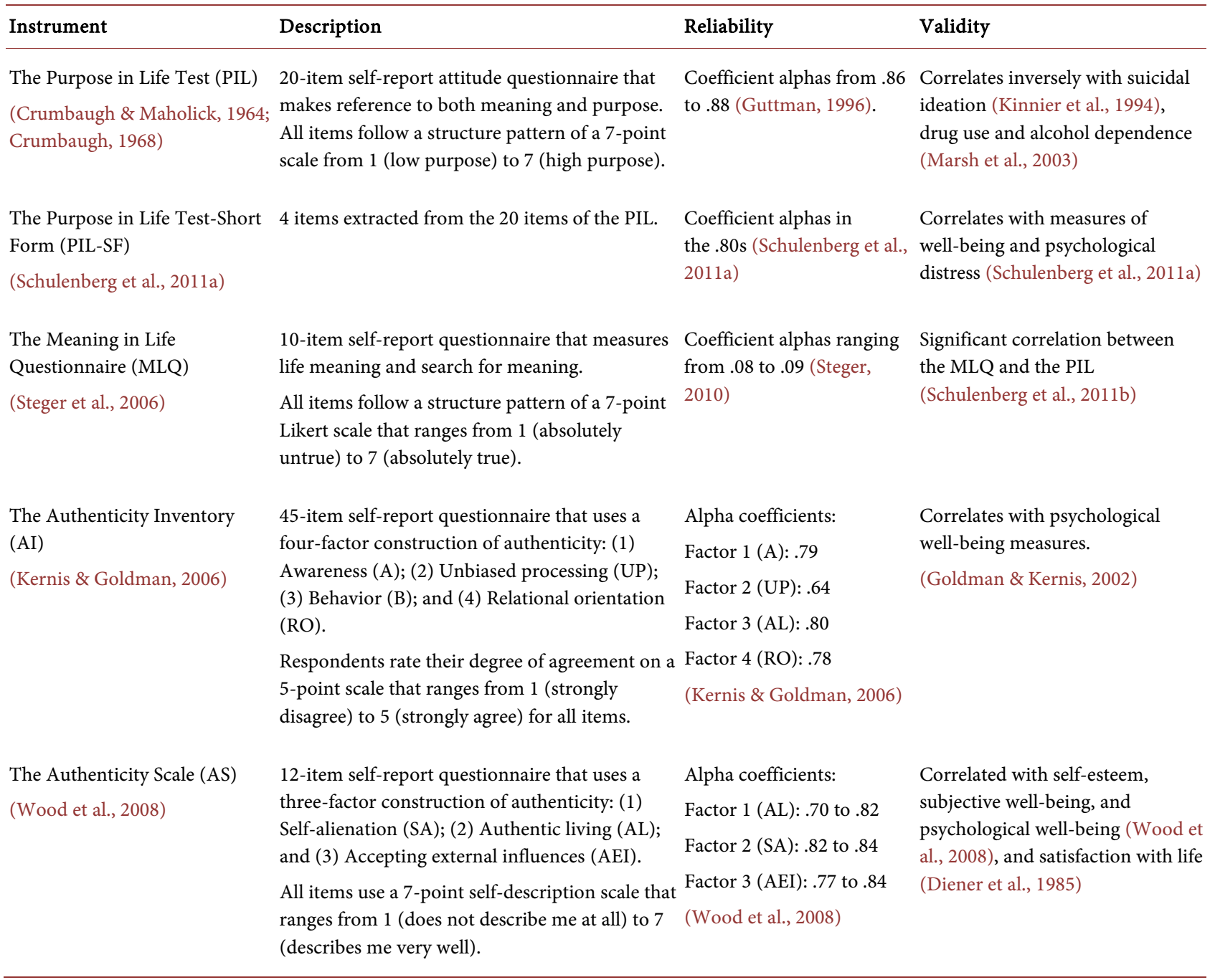

\section{Conclusion and Recommendations}

Depression is a growing and pernicious psychological condition across the lifespan that has been exacerbated by the current COVID-19 pandemic, which triggered a surge in experiences of emptiness, sadness, and erosion of meaning in life. Purpose and meaning in life improve adaptive coping by acting as a protective factor and buffer against adversity, depression, and suicidal tendencies. This paper has presented a comprehensive, practical, and evidence-based existential model of depression that can be integrated into most therapeutic modalities. The model can be used to promote preventing factors in positive youth development, develop protective factors in high-risk individuals with vulnerability to depression, and treat those experiencing depression or other internalizing disorders.

\section{Conflicts of Interest}

The author declares no conflicts of interest regarding the publication of this paper. 


\section{References}

American Psychiatric Association (2013). Diagnostic and Statistical Manual of Mental Disorders (5th ed.). American Psychiatric Association. https://doi.org/10.1176/appi.books.9780890425596

Andolfi, M., Ellenwood, A. E., \& Wendt, R. N. (1993). The Creation of the Fourth Planet: Beginning Therapists and Supervisors Inducing Change in Families. The American Journal of Family Therapy, 21, 301-312. https://doi.org/10.1080/01926189308251001

APA Presidential Task Force on Evidence-Based Practice (2006). Evidence-Based Practice in Psychology. American Psychologist, 61, 271-285. https://doi.org/10.1037/0003-066X.61.4.271

Arkowitz, H. (1992). Integrative Theories of Therapy. In D. K. Freedheim, H. J. Freudenberger, J. W. Kessler, S. B. Messer, D. R. Peterson, H. H. Strupp, \& P. L. Wachtel (Eds.), The History of Psychotherapy: A Century of Change (pp. 261-303). American Psychiatric Association.

Arslan, G., Yıldırım, M., Karataş, Z., Kabasakal, Z., \& Kılınç, M. (2020). Meaningful Living to Promote Complete Mental Health among University Students in the Context of the COVID-19 Pandemic. International Journal of Mental Health and Addiction, 1-13. https://doi.org/10.1007/s11469-020-00416-8

Baldwin, M. (Ed.). (2013). The Use of Self in Therapy (3rd ed.). Routledge. https://doi.org/10.4324/9780203076156

Barnes, H. E. (1959). Humanistic Existentialism: The Literature of Possibility. University of Nebraska Press.

Basescu, S. (1963). Existential Therapy. In A. Deutsch, \& H. Fishman (Eds.), The Encyclopedia of Mental Health (Vol. 2, pp. 583-595). Franklin Watts.

https://doi.org/10.1037/11549-020

Basile, B., Tenore, K., \& Mancini, F. (2018). Investigating Schema Therapy Constructs in Individuals with Depression. Journal Psychology and Clinical Psychiatry, 9, 214-221. https://doi.org/10.15406/jpcpy.2018.09.00524

Battista, J., \& Almond, R. (1973). The Development of Meaning in Life. Psychiatry, 36, 409-427. https://doi.org/10.1080/00332747.1973.11023774

Baumeister, R. F. (1991). Meanings of Life. Guilford.

Baumeister, R. F., \& Newman, L. S. (1994). How Stories Make Sense of Personal Experiences: Motives That Shape Autobiographical Narratives. Personality and Social Psychology Bulletin, 20, 676-690. https://doi.org/10.1177/0146167294206006

Baumeister, R. F., \& Vohs, K. D. (2002). The Pursuit of Meaningfulness in Life. In C. R. Snyder, \& S. J. Lopez (Eds.), Handbook of Positive Psychology (pp. 608-618). Oxford University Press.

Baumeister, R. F., \& Wilson, B. (1996). Life Stories and the Four Need for Meaning. Psychological Inquiry, 7, 322-325. https://doi.org/10.1207/s15327965pli0704_2

Beck, A. T., Brown, G., Berchick, R. J., Stewart, B. L., \& Steer, R. A. (1990). Relationship between Hopelessness and Ultimate Suicide: A Replication with Psychiatric Outpatients. American Journal of Psychiatry, 147, 190-195.

https://doi.org/10.1176/ajp.147.2.190

Bell, T., Montague, J., Elander, J., \& Gilbert, P. (2020). “A Definite Fee-It Moment”: Embodiment, Externalisation and Emotion during Chair-Work in Compassion-Focused Therapy. Counselling and Psychotherapy Research, 20, 143-153.

https://doi.org/10.1002/capr.12248

Blair, L. (2010). A Critical Review of the Scientist-Practitioner Model for Counselling 
Psychology. Counselling Psychology Review, 25, 19-30.

https://psycnet.apa.org/record/2011-04080-002

Bloomgarden, A., \& Mennuti, R. B. (2009). Therapist Self-Disclosure: Beyond the Taboo. In A. Bloomgarden, \& R. B. Mennuti (Eds.), Psychotherapist Revealed: Therapists Speak about Self-Disclosure in Psychotherapy (pp. 3-15). Routledge/Taylor \& Francis Group.

Bohart, A. C. (1999). Intuition and Creativity in Psychotherapy. Journal of Constructivist Psychology, 12, 287-311. https://doi.org/10.1080/107205399266028

Bonebright, C. A., Clay, D. L., \& Ankenmann, R. D. (2000). The Relationship of Workaholism with Work-Life Conflict, Life Satisfaction, and Purpose in Life. Journal of Counseling Psychology, 47, 469-477. https://doi.org/10.1037/0022-0167.47.4.469

https://psycnet.apa.org/buy/2000-02442-007

Boyraz, G., Waits, J. B., \& Felix, V. A. (2014). Authenticity, Life Satisfaction, and Distress: A Longitudinal Analysis. Journal of Counseling Psychology, 61, 498-505. https://doi.org/10.1037/cou0000031

Brassai, L., Piko, B. F., \& Steger, M. F. (2011). Meaning in Life: Is It a Protective Factor for Adolescents' Psychological Health? International Journal of Behavioral Medicine, 18, 44-51. https://doi.org/10.1007/s12529-010-9089-6

Buber, M. (1970). I and Thou (trans. W. Kaufmann). Charles Scribner's Sons

Bugental, J. F. (1965). The Search for Authenticity. An Existential-Analytic Approach to Psychotherapy. Holt, Rinehart \& Winston.

Bugental, J. F. (1976). The Search for Existential Identity. Jossey-Bass.

Bugental, J.F. (1987). The Art of the Psychotherapist. Norton.

Bulut, S. (2019) Socialization Helps the Treatment of Depression in Modern Life. Open Journal of Depression, 8, 41-47. https://doi.org/10.4236/ojd.2019.82005

http://creativecommons.org/licenses/by/4.0/

Cain, D. J. (2007). What Every Therapist Should Know, Be and Do: Contributions from Humanistic Psychotherapies. Journal of Contemporary Psychotherapy, 37, 3-10. https://doi.org/10.1007/s10879-006-9028-7

Cain, D. J. (2010). Humanistic Psychotherapies. In I. B. Weiner and W. E. Craighead (Eds.), The Corsini Encyclopedia of Psychology (pp. 1-4). John Wiley \& Sons, Inc. https://doi.org/10.1002/9780470479216.corpsy0423

Cain, D. J. (2016). Toward a Research-Based Integration of Optimal Practices of Humanistic Psychotherapies. In D. J. Cain, K. Keenan, \& S. Rubin (Eds.), Humanistic Psychotherapies: Handbook of Research and Practice (2nd ed., pp. 485-535). American Psychiatric Association. https://content.apa.org/doi/10.1037/14775-016 https://doi.org/10.1037/14775-016

Cain, D. J. (Ed.) (2002). Humanistic Psychotherapies: Handbook of Research and Practice. American Psychiatric Association. https://doi.org/10.1037/10439-000

Carson, D. K., \& Becker, K. W. (2004). When Lightning Strikes: Reexamining Creativity in Psychotherapy. Journal of Counseling \& Development, 82, 111-115. https://doi.org/10.1002/j.1556-6678.2004.tb00292.x

Cashdan, S. (1988). Object Relations Therapy: Using the Relationship. Norton \& Co.

Castiglioni, M., \& Gaj, N. (2020). Fostering the Reconstruction of Meaning among the General Population during the COVID-19 Pandemic. Frontiers in Psychology, 11, Article ID: 567419. https://doi.org/10.3389/fpsyg.2020.567419

Castonguay, L. G., \& Goldfried, M. R. (1994). Psychotherapy Integration: An Idea Whose 
Time Has Come. Applied and Preventive Psychology, 3, 159-172.

https://doi.org/10.1016/S0962-1849(05)80068-X

Castonguay, L. G., Reid Jr., J. J., Halperin, G. S., \& Goldfried, M. R. (2003). Psychotherapy Integration. In G. Stricker, T. A. Widiger, \& I. B. Weiner (Eds.), Handbook of Psychology: Clinical Psychology(Vol. 8, pp. 327-366). John Wiley \& Sons.

https://doi.org/10.1002/0471264385.wei0813

Cooper, M. (2008). Existential Psychotherapy. In J. L. Lebow (Ed.), Twenty-First Century Psychotherapies. Contemporary Approaches to Theory and Practice (pp. 237-276). Wiley \& Sons.

Cooper, M. (2012). The Existential Counselling Primer: A Concise, Accessible and Comprehensive Introduction. PCCS Books.

Correia, E. A., Cooper, M., Berdondini, L., \& Correia, K. (2016). Existential Psychotherapies: Similarities and Differences among the Main Branches. Journal of Humanistic Psychology, 58, 119-143. https://doi.org/10.1177/0022167816653223

Craig, M., Vos, J., Cooper, M., \& Correia, E. A. (2016). Existential Psychotherapies. In D. J. Cain, K. Keenan, \& S. Rubin (Eds.), Humanistic Psychotherapies: Handbook of Research and Practice (pp. 283-317). American Psychiatric Association. https://doi.org/10.1037/14775-010

Crumbaugh, J. C. (1968). Cross-Validation of Purpose-in-Life Test Based on Frankl's Concepts. Journal of Individual Psychology, 24, 74-81.

https://psycnet.apa.org/record/1968-11401-001

Crumbaugh, J. C. (1977). The Seeking of Noetic Goals Test (SONG): A Complementary Scale to the Purpose in Life Test (PIL). Journal of Clinical Psychology, 33, 900-907. https://doi.org/10.1002/1097-4679(197707)33:3\%3C900::AID-JCLP2270330362\%3E3.0. CO;2-8

Crumbaugh, J. C., \& Maholick, L. T. (1964). An Experimental Study in Existentialism: The Psychometric Approach to Frankl's Concept of Noogenic Neurosis. Journal of Clinical Psychology, 20, 200-207.

https://doi.org/10.1002/1097-4679(196404)20:2\%3C200::AID-JCLP2270200203\%3E3.0. $\mathrm{CO} ; 2-\mathrm{U}$

Damon, W., Menon, J., \& Cotton Bronk, K. (2003). The Development of Purpose during Adolescence. Applied Developmental Science, 7, 119-128.

https://doi.org/10.1207/S1532480XADS0703_2

De Jong, E. M., Ziegler, N., \& Schippers, M. C. (2020). From Shattered Goals to Meaning in Life: Life Crafting in Times of the COVID-19 Pandemic. Frontiers in Psychology, 11, Article ID: 577708. https://doi.org/10.3389/fpsyg.2020.577708

Debats, D. L., Van der Lubbe, P. M., \& Wezeman, F. R. (1993). On the Psychometric Properties of the Life Regard Index (LRI): A Measure of Meaningful Life: An Evaluation in Three Independent Samples Based on the Dutch Version. Personality and Individual Differences, 14, 337-345. https://doi.org/10.1016/0191-8869(93)90132-M

Deci, E. L., \& Ryan, R. M. (1995). Human Agency: The Basis for True Self-Esteem. In M. H. Kernis (Ed.), Efficacy, Agency, and Self-Esteem (pp. 31-49). Springer. https://doi.org/10.1007/978-1-4899-1280-0_3

Deci, E. L., \& Ryan, R. M. (2008). Self-Determination Theory: A Macrotheory of Human Motivation, Development, and Health. Canadian Psychology/Psychologie Canadienne, 49, 182-185. https://doi.org/10.1037/a0012801

Dewan, C. J. (2006). Use of Self: A Primer Revisited. Clinical Social Work Journal, 34, 543-558. https://doi.org/10.1007/s10615-005-0021-5

Diener, E., Emmons, R.A., Larsen, R.J., \& Griffin, S. (1985). The Satisfaction with Life 
Scale. Journal of Personality Assessment, 49, 71-75. https://doi.org/10.1207/s15327752jpa4901_13

Diener, E., Fujita, F., Tay, L., \& Biswas-Diener, R. (2012). Purpose, Mood, and Pleasure in Predicting Satisfaction Judgments. Social Indicators Research, 105, 333-341. https://doi.org/10.1007/s11205-011-9787-8

Ebert, D. D., \& Cuijpers, P. (2018). It is Time to Invest in the Prevention of Depression. JAMA Network Open, 1, Article ID: e180335. https://doi.org/10.1001/jamanetworkopen.2018.0335 https://jamanetwork.com/journals/jamanetworkopen/fullarticle/2686034

Ehlers, A., Maercker, A., \& Boos, A. (2000). Posttraumatic Stress Disorder Following Political Imprisonment: The Role of Mental Defeat, Alienation, and Perceived Permanent Change. Journal of Abnormal Psychology, 109, 45-55.

https://doi.org/10.1037/0021-843X.109.1.45

Elliott, R, Watson, J. C. Timulak, L., Sharbanee, J., Barkham, M., \& Lutz, W., Castonguay, L. (Eds.) (2021) Research on Humanistic-Experiential Psychotherapies: Updated Review. In Bergin and Garfield's Handbook of Psychotherapy and Behavior Change (7th ed.). Wiley. (In Press) https://strathprints.strath.ac.uk/74362/

Elliott, R., Greenberg, L. S., Watson, J., Timulak, L., \& Freire, E. (2013). Research on Humanistic-Experiential Psychotherapies. In M. J. Lambert (Ed.), Bergin \& Garfield's Handbook of Psychotherapy and Behavior Change (6th ed., pp. 495-538). Wiley.

Emmons, R. A. (2003). Personal Goals, Life Meaning, and Virtue: Wellsprings of a Positive Life. In C. L. M. Keyes, \& J. Haidt (Eds.), Flourishing: Positive Psychology and the Life Well-Lived (pp. 105-128). American Psychiatric Association. https://doi.org/10.1037/10594-005

Epston, D. \& White, M. (1992). Experience, Contradiction, Narrative and Imagination. Dulwich Centre Publications.

Erikson, E. H. (1968). Identity: Youth and Crisis. Norton \& Co.

Etherington, K. (2001). Writing Qualitative Research-A Gathering of Selves. Counselling and Psychotherapy Research, 1, 119-125. https://doi.org/10.1080/14733140112331385158

Frank, J. D., \& Frank, J. B. (1993). Persuasion and Healing: A Comparative Study of Psychotherapy. Johns Hopkins University Press.

Frankl, V. E. (1955). The Doctor and the Soul: From Psychotherapy to Logotherapy. Vintage Books.

Frankl, V. E. (1959). Man’s Search for Meaning. Simon \& Schuster.

Frankl, V. E. (1967). Psychotherapy and Existentialism: Selected Papers on Logotherapy. Washington Square Press.

Frankl, V. E. (1969). The Will to Meaning: Foundations and Applications of Logotherapy. New American Library.

Frankl, V. E. (1972). The Feeling of Meaninglessness: A Challenge to Psychotherapy. The American Journal of Psychoanalysis, 32, 85-89. https://doi.org/10.1007/BF01872487

Friedman, N. (2005). Experiential Listening. Journal of Humanistic Psychology, 45, 217-238. https://doi.org/10.1177/0022167804274355

Friese, M., Messner, C., \& Schaffner, Y. (2012). Mindfulness Meditation Counteracts Self-Control Depletion. Consciousness and Cognition, 21, 1016-1022. https://doi.org/10.1016/j.concog.2012.01.008

Geller, J. D. (2003). Self-Disclosure in Psychoanalytic-Existential Therapy. Journal of 
Clinical Psychology, 59, 541-554. https://doi.org/10.1002/jclp.10158

Geller, S. M., \& Greenberg, L. S. (2002). Therapeutic Presence: Therapists' Experience of Presence in the Psychotherapy Encounter. Person-Centered \& Experiential Psychotherapies, 1, 71-86. https://doi.org/10.1080/14779757.2002.9688279

Gendlin, E. T. (1996). Focusing-Oriented Psychotherapy. Guilford Press.

Goldfried, M. R., Burckell, L. A., \& Eubanks-Carter, C. (2003). Therapist Self-Disclosure in Cognitive-Behavior Therapy. Journal of Clinical Psychology, 59, 555-568. https://doi.org/10.1002/jclp.10159

Goldman, B. M., \& Kernis, M. H. (2002). The Role of Authenticity in Healthy Psychological Functioning and Subjective Well-Being. Annals of the American Psychotherapy Association, 5, 18-20. https://psycnet.apa.org/record/2002-11420-003

Golomb, J. (1995). In Search of Authenticity: Existentialism from Kierkegaard to Camus. Routledge.

Greenberg, L. S. (2011). Emotion-Focused Therapy. American Psychiatric Association.

Greenberg, L. S., \& Johnson, S. (1988). Emotionally Focused Therapy for Couples. Guilford Press.

Greenberg, L. S., \& Pascual-Leone, A. (2006). Emotion in Psychotherapy: A Practice-Friendly Research Review. Journal of Clinical Psychology, 62, 611-630. https://doi.org/10.1002/jclp.20252

Greenberg, L. S., Watson, J. C., \& Lietaer, G. (Eds.). (1998). Handbook of Experiential Psychotherapy. Guilford Press.

Grencavage, L. M., \& Norcross, J. C. (1990). Where Are the Commonalities among the Therapeutic Common Factors? Professional Psychology: Research and Practice, 21, 372-378. https://doi.org/10.1037/0735-7028.21.5.372

Gunnell, D., Appleby, L., Arensman, E., Hawton, K., John, A., Kapur, N. et al. (2020). Suicide Risk and Prevention during the COVID-19 Pandemic. The Lancet Psychiatry, 7, 468-471. https://doi.org/10.1016/S2215-0366(20)30171-1

Guttman, D. (1996). Logotherapy for the Helping Professional: Meaningful Social Work. Springer.

Harlow, L. L., Newcomb, M. D., \& Bentler, P. M. (1986). Depression, Self-Derogation, Substance Use, and Suicide Ideation: Lack of Purpose in Life as a Mediational Factor. Journal of Clinical Psychology, 42, 5-21.

https://doi.org/10.1002/1097-4679(198601)42:1\%3C5::AID-JCLP2270420102\%3E3.0.C $\underline{0 ; 2-9}$

Harter, S., Marold, D. B., Whitesell, N. R., \& Cobbs, G. (1996). A Model of the Effects of Perceived Parent and Peer Support on Adolescent False Self-Behavior. Child Development, 67, 360-374. https://doi.org/10.2307/1131819

Harter, S., Waters, P. L., \& Whitesell, N. R. (1997). Lack of Voice as a Manifestation of False Self-Behavior among Adolescents: The School Setting as a Stage upon Which the Drama of Authenticity Is Enacted. Educational Psychologist, 32, 153-173. https://doi.org/10.1207/s15326985ep3203_2

Hayes, S. C., Luoma, J. B., Bond, F. W., Masuda, A., \& Lillis, J. (2006). Acceptance and Commitment Therapy: Model, Processes and Outcomes. Behaviour Research and Therapy, 44, 1-25. https://doi.org/10.1016/j.brat.2005.06.006

Heidegger, M. (1962). Being and Time (trans. J. Maquarrie and E.H. Freund). Harper \& Row.

Held, B. S. (2002). The Tyranny of the Positive Attitude in America: Observation and Speculation. Journal of Clinical Psychology, 58, 965-991. 
https://doi.org/10.1002/jclp.10093

Henretty, J. R., \& Levitt, H. M. (2010). The Role of Therapist Self-Disclosure in Psychotherapy: A Qualitative Review. Clinical Psychology Review, 30, 63-77.

https://doi.org/10.1016/j.cpr.2009.09.004

Hetrick, S. E., Parker, A. G., Hickie, I. B., Purcell, R., Yung, A. R., \& McGorry, P. D. (2008). Early Identification and Intervention in Depressive Disorders: Towards a Clinical Staging Model. Psychotherapy and Psychosomatics, 77, 263-270. https://doi.org/10.1159/000140085

Higgins, E. T. (1987). Self-Discrepancy: A Theory Relating Self and Affect. Psychological Review, 94, 319-340. https://doi.org/10.1037/0033-295X.94.3.319

Higgins, E. T., Klein, R., \& Strauman, T. (1985). Self-Concept Discrepancy Theory: A Psychological Model for Distinguishing among Different Aspects of Depression and Anxiety. Social Cognition, 3, 51-76. https://doi.org/10.1521/soco.1985.3.1.51

Hill, C. E., \& Knox, S. (2001). Self-Disclosure. Psychotherapy: Theory, Research, Practice, Training, 38, 413-417. https://doi.org/10.1037/0033-3204.38.4.413

Hill, P. L., \& Turiano, N. A. (2014). Purpose in Life as a Predictor of Mortality across Adulthood. Psychological Science, 25, 1482-1486. https://doi.org/10.1177/0956797614531799

Hoffman, L., Vallejos, L., Cleare-Hoffman, H. P., \& Rubin, S. (2015). Emotion, Relationship, and Meaning as Core Existential Practice: Evidence-Based Foundations. Journal of Contemporary Psychotherapy, 45, 11-20. https://doi.org/10.1007/s10879-014-9277-9

Horney, K. (1951). Neurosis and Human Growth: The Struggle toward Self-Realization. Routledge.

House, R. (2007). The Be-Coming of a Therapist: Experiential Learning, Self-Education and the Personal/Professional Nexus. British Journal of Guidance \& Counselling, 35, 427-440. https://doi.org/10.1080/03069880701593524

Husserl, E. (1965). Phenomenology and the Crisis of Philosophy. Harper \& Row.

James W. (1890). The Principles of Psychology (Vol. 1). Henry Holt and Company. https://doi.org/10.1037/10538-000

Johnson, J. T., Robinson, M. D., \& Mitchell, E. B. (2004). Inferences about the Authentic Self: When Do Actions Say More than Mental States? Journal of Personality and Social Psychology, 87, 615-630. https://doi.org/10.1037/0022-3514.87.5.615

Joseph, S. J., Gonçalves, A. P., Paul, A., \& Bhandari, S. S. (2020). Theoretical Orientation of a Range of Psychological Approaches to Address Mental Health Concerns during the COVID-19 Pandemic. Asian Journal of Psychiatry, 53, Article ID: 102221.

https://doi.org/10.1016/j.ajp.2020.102221

Joshi, C., Marszalek, J. M., Berkel, L. A., \& Hinshaw, A. B. (2014). An Empirical Investigation of Viktor Frankl's Logotherapeutic Model. Journal of Humanistic Psychology, 54, 227-253. https://doi.org/10.1177/0022167813504036

Kabat-Zinn, J. (1990). Full Catastrophe Living: Using the Wisdom of Your Mind and Body to Face Stress, Pain, and Illness. Delacorte.

Kasper, L. B., Hill, C. E., \& Kivlighan Jr., D. M. (2008). Therapist Immediacy in Brief Psychotherapy: Case Study I. Psychotherapy: Theory, Research, Practice, Training, 45, 281-297. https://doi.org/10.1037/a0013305

Kernis, M. H. \& Goldman, B. M. (2006). A Multicomponent Conceptualization of Authenticity: Theory and Research. Advances in Experimental Social Psychology, 38, 283-357. https://doi.org/10.1016/S0065-2601(06)38006-9

Kiesler, D. J. (1988). Therapeutic Metacommunication: Therapist Impact Disclosure as 
Feedback in Psychotherapy. Consulting Psychologists Press.

King, L. A., Hicks, J. A., Krull, J. L., \& Del Gaiso, A. K. (2006). Positive Affect and the Experience of Meaning in Life. Journal of Personality and Social Psychology, 90, 179-196. https://doi.org/10.1037/0022-3514.90.1.179

Kinnier, R. T., Metha, A. T., Keim, J. S., Okey, J. L., Adler-Tabia, R., Berry, M., \& Mulvenon, S. (1994). Depression, Meaninglessness, and Substance Abuse in "Normal" and Hospitalized Adolescents. Journal of Alcohol and Drug Education, 39, 101-111.

Kirkman, M. (1999). I Didn't Interview Myself: The Researcher as Participant in Narrative Research. Annual Review of Health Social Science, 9, 32-41.

https://doi.org/10.5172/hesr.1999.9.1.32

Kleftaras, G., \& Psarra, E. (2012). Meaning in Life, Psychological Well-Being and Depressive Symptomatology: A Comparative Study. Psychology, 3, 337-345.

Klinger, E. (1977). Meaning \& Void: Inner Experience and the Incentives in People's Lives. University of Minnesota Press.

Kracen, A. C., \& Bairdb, K. (2017). Exploring Influence and Autoethnography: A Dialogue between Two Counselling Psychologists. The European Journal of Counselling Psychology, 6, 162-173. https://doi.org/10.5964/ejcop.v6i1.122

Krug, O. T. (2009). James Bugental and Irvin Yalom: Two Masters of Existential Therapy Cultivate Presence in the Therapeutic Encounter. Journal of Humanistic Psychology, 49, 329-354. https://doi.org/10.1177/0022167809334001

Kwon, P. (2000). Hope and Dysphoria: The Moderating Role of Defense Mechanisms. Journal of Personality, 68, 199-223. https://doi.org/10.1111/1467-6494.00095

Laing, R. D. (1967). The Politics of Experience and the Bird of Paradise. Penguin.

Lakey, C. E., Kernis, M. H., Heppner, W. L., \& Lance, C. E. (2008). Individual Differences in Authenticity and Mindfulness as Predictors of Verbal Defensiveness. Journal of Research in Personality, 42, 230-238. https://doi.org/10.1016/j.jrp.2007.05.002

Längle, A., Orgler, C., \& Kundi, M. (2003). The Existence Scale: A New Approach to Assess the Ability to Find Personal Meaning in Life and to Reach Existential Fulfillment. European Psychotherapy, 4, 135-151. https://www.existenzanalyse.org/wp-content/uploads/ESK-Article_-_EP_2003.pdf

Leahy, R. L. (2002). A Model of Emotional Schemas. Cognitive and Behavioral Practice, 9, 177-190. https://doi.org/10.1016/S1077-7229(02)80048-7

Leary, M. R. (2003). Interpersonal Aspects of Optimal Self-Esteem and the Authentic Self. Psychological Inquiry, 14, 52-54. https://www.jstor.org/stable/1449041

Lewinsohn, P. M., Rohde, P., Seeley, J. R., Klein, D. N., \& Gotlib, I. H. (2000). Natural Course of Adolescent Major Depressive Disorder in a Community Sample: Predictors of Recurrence in Young Adults. American Journal of Psychiatry, 157, 1584-1591. https://doi.org/10.1176/appi.ajp.157.10.1584

Liggins, J., Kearns, R. A., \& Adams, P. J. (2013). Using Autoethnography to Reclaim the 'Place of Healing' in Mental Health Care. Social Science \& Medicine, 91, 105-109. https://doi.org/10.1016/j.socscimed.2012.06.013

Loevinger, J. (1993). Ego Development: Questions of Method and Theory. Psychological Inquiry, 4, 56-63. https://doi.org/10.1207/s15327965pli0401_12

Lopez, F. G., \& Rice, K. G. (2006). Preliminary Development and Validation of a Measure of Relationship Authenticity. Journal of Counseling Psychology, 53, 362-371.

https://doi.org/10.1037/0022-0167.53.3.362

Lovibond, P. F., \& Lovibond, S. H. (1995). The Structure of Negative Emotional States: Comparison of the Depression Anxiety Stress Scales (DASS) with the Beck Depression 
and Anxiety Inventories. Behaviour Research and Therapy, 33, 335-343. https://doi.org/10.1016/0005-7967(94)00075-U

Lum, W. (2002). The Use of Self of the Therapist. Contemporary Family Therapy, 24, 181-197. https://doi.org/10.1023/A:1014385908625

Luo, M., Guo, L., Yu, M., Jiang, W., \& Wang, H. (2020). The Psychological and Mental Impact of Coronavirus Disease 2019 (COVID-19) on Medical Staff and General Public-A Systematic Review and Meta-Analysis. Psychiatry Research, 291, Article ID: 113190. https://doi.org/10.1016/j.psychres.2020.113190

Madill, A., \& Doherty, K. (1994). 'So You Did What You Wanted Then': Discourse Analysis, Personal Agency, and Psychotherapy. Journal of Community \& Applied Social Psychology, 4, 261-273. https://doi.org/10.1002/casp.2450040406

Mahrer, A. R. (1996). The Complete Guide to Experiential Psychotherapy. John Wiley \& Sons.

Mahrer, A. R. (2011). Transformation: A Glimpse into the Future of How Change Will Come about. Howard Gontovnick Publications.

Marco, J. H., Alonso, S., \& Baños, R. (2020). Meaning-Making as a Mediator of Anxiety and Depression Reduction during Cognitive Behavioral Therapy Intervention in Participants with Adjustment Disorders. Clinical Psychology \& Psychotherapy, 28, 325-333. https://doi.org/10.1002/cpp.2506

Marsh, A., Smith, L., Piek, J., \& Saunders, B. (2003). The Purpose in Life Scale: Psychometric Properties for Social Drinkers and Drinkers in Alcohol Treatment. Educational and Psychological Measurement, 63, 859-871.

https://doi.org/10.1177/0013164403251040

Mascaro, N., \& Rosen, D. H. (2005). Existential Meaning's Role in the Enhancement of Hope and Prevention of Depressive Symptoms. Journal of Personality, 73, 985-1014. https://doi.org/10.1111/j.1467-6494.2005.00336.x

Mascaro, N., \& Rosen, D. H. (2006). The Role of Existential Meaning as a Buffer against Stress. Journal of Humanistic Psychology, 46, 168-190.

https://doi.org/10.1177/0022167805283779

Maslow, A. H. (1968). Toward a Psychology of Being (2nd ed.). Van Nostrand Reinhold.

May, R. (1958). Contributions of Existential Psychotherapy. In R. May, E. Angel, \& H. F. Ellenberger (Eds.), Existence: A New Dimension in Psychiatry and Psychology (pp. 37-91). Basic Books/Hachette Book Group. https://doi.org/10.1037/11321-002

May, R. (1969). Love and Will. Norton \& Company.

May, R. (1981). Freedom and Destiny. Norton \& Company.

May, R. (1983). The Discovery of Being. Norton \& Company.

McAdams, D. P. (1996). Personality, Modernity, and the Storied Self: A Contemporary Framework for Studying Persons. Psychological Inquiry, 7, 295-321. https://doi.org/10.1207/s15327965pli0704_1

McGregor, I., \& Little, B. R. (1998). Personal Projects, Happiness, and Meaning: On Doing Well and Being Yourself. Journal of Personality and Social Psychology, 74, 494-512. https://doi.org/10.1037/0022-3514.74.2.494

McKnight, P. E., \& Kashdan, T. B. (2009). Purpose in Life as a System That Creates and Sustains Health and Well-Being: An Integrative, Testable Theory. Review of General Psychology, 13, 242-251. https://doi.org/10.1037/a0017152

McLaughlin, K. A. (2011). The Public Health Impact of Major Depression: A Call for Interdisciplinary Prevention Efforts. Prevention Science, 12, 361-371.

https://doi.org/10.1007/s11121-011-0231-8 
Medlock, G. (2012). The Evolving Ethic of Authenticity: From Humanistic to Positive Psychology. The Humanistic Psychologist, 40, 38-57. https://doi.org/10.1080/08873267.2012.643687

Mennin, D. S. (2006). Emotion Regulation Therapy: An Integrative Approach to Treatment-Resistant Anxiety Disorders. Journal of Contemporary Psychotherapy, 36, 95-105. https://doi.org/10.1007/s10879-006-9012-2

Moreno, J. L. (1977). Psychodrama (Vol. 1). Beacon House.

Morgan, J., \& Farsides, T. (2009). Psychometric Evaluation of the Meaningful Life Measure. Journal of Happiness Studies, 10, 351-366. https://doi.org/10.1007/s10902-008-9093-6

Mørken, D. (2019). The Authenticity Scale as an Outcome Measure for Psychological Therapies. Doctoral Dissertation, University of Roehampton. https://ethos.bl.uk/OrderDetails.do?uin=uk.bl.ethos.800420

Ormel, J., Cuijpers, P., Jorm, A., \& Schoevers, R. A. (2020). What Is Needed to Eradicate the Depression Epidemic, and Why. Mental Health \& Prevention, 17, Article ID: 200177. https://doi.org/10.1016/j.mhp.2019.200177

Pennebaker, J. W., Kiecolt-Glaser, J. K., \& Glaser, R. (1988). Disclosure of Traumas and Immune Function: Health Implications for Psychotherapy. Journal of Consulting and Clinical Psychology, 56, 239-245. https://doi.org/10.1037/0022-006X.56.2.239

Perls, F. (1969). Gestalt Therapy Verbatim. Real People Press.

Perls, F., Hefferline, G., \& Goodman, P. (1951). Gestalt Therapy. Julian Press.

Phillips, A. G., \& Silvia, P. J. (2010). Individual Differences in Self-Discrepancies and Emotional Experience: Do Distinct Discrepancies Predict Distinct Emotions? Personality and Individual Differences, 49, 148-151. https://doi.org/10.1016/j.paid.2010.03.010

Pinto, S., Soares, J., Silva, A., Curral, R., \& Coelho, R. (2020). COVID-19 Suicide Survivors-A Hidden Grieving Population. Frontiers in Psychiatry, 11, Article ID: 626807. https://doi.org/10.3389/fpsyt.2020.626807

Pos, A. E., \& Greenberg, L. S. (2012). Organizing Awareness and Increasing Emotion Regulation: Revising Chair Work in Emotion-Focused Therapy for Borderline Personality Disorder. Journal of Personality Disorders, 26, 84-107.

https://doi.org/10.1521/pedi.2012.26.1.84

Rafaeli, E., Maurer, O., \& Thoma, N. C. (2014). Working with Modes in Schema Therapy. In N. C. Thoma \& D. McKay (Eds.), Working with Emotion in Cognitive-Behavioral Therapy: Techniques for Clinical Practice (pp. 263-287). Guilford Publications.

Reger, M. A., Stanley, I. H., \& Joiner, T. E. (2020). Suicide Mortality and Coronavirus Disease 2019-A Perfect Storm? JAMA Psychiatry, 77, 1093-1094.

https://doi.org/10.1001/jamapsychiatry.2020.1060

Reker, G. T. (2005). Meaning in Life of Young, Middle-Aged, and Older Adults: Factorial Validity, Age, and Gender Invariance of the Personal Meaning Index (PMI). Personality and Individual Differences, 38, 71-85. https://doi.org/10.1016/j.paid.2004.03.010

Reker, G. T., \& Wong, P. T. P. (1988). Aging as an Individual Process: Toward a Theory of Personal Meaning. In J. E. Birren, \& V. L. Bengtson (Eds.), Emergent Theories of Aging (pp. 214-246). Springer.

Reker, G. T., Peacock, E. J., \& Wong, P. T. (1987). Meaning and Purpose in Life and Well-Being: A Life-Span Perspective. Journal of Gerontology, 42, 44-49.

https://doi.org/10.1093/geronj/42.1.44

Rogers, C. R. (1942). Counseling and Psychotherapy: Newer Concepts in Practice. Hough- 
ton Mifflin.

Rogers, C. R. (1951). Client-Centered Therapy: Its Current Practice, Implications, and Theory. Houghton Mifflin.

Rogers, C. R. (1961). On Becoming a Person: A Therapist's Point of View of Psychotherapy. Constable.

Rogers, C. R. (1980). A Way of Being. Houghton Mifflin.

Rogers, J. R. (2001). Theoretical Grounding: The "Missing Link" in Suicide Research. Journal of Counseling \& Development, 79, 16-25. https://doi.org/10.1002/j.1556-6676.2001.tb01939.x

Rosen, H. (1996). Meaning-Making Narratives: Foundations for Constructivist and Social Constructionist Psychotherapies. In H. Rosen \& K. Kuehlwein (Eds.), Constructing Realities (pp. 3-54). Jossey-Bass.

Rosenberg, M. (1965). Society and the Adolescent Self-Image. Princeton University Press. https://doi.org/10.1515/9781400876136

Rowlands, J. (1995). Empowerment Examined. Development in Practice, 5, 101-107. https://doi.org/10.1080/0961452951000157074

Ruffin, J. E. (1984). The Anxiety of Meaninglessness. Journal of Counseling \& Development, 63, 40-42. https://doi.org/10.1002/j.1556-6676.1984.tb02678.x

Ryff, C. D., \& Singer, B. H. (1998). The Role of Purpose in Life and Personal Growth in Positive Human Health. In P. Wong \& P. Fry (Eds.), The Human Quest for Meaning (pp. 213-236). Erlbaum.

Ryff, C. D., \& Singer, B. H. (2008). Know Thyself and Become What You Are: A Eudaimonic Approach to Psychological Well-Being. Journal of Happiness Studies, 9, 13-39.

https://doi.org/10.1007/s10902-006-9019-0 http://hdl.handle.net/10.1007/s10902-006-9019-0

Samman, E., \& Santos, M. E. (2009). Agency and Empowerment. A Review of Concepts, Indicators and Empirical Evidence. Oxford Poverty \& Human Development Initiative (OPHI). https://ora.ox.ac.uk/objects/uuid:974e9ca9-7e3b-4577-8c13-44a2412e83bb

Sartre, J. P. (1973). Existentialism and Humanism (trans. P. Mairet). Methuen.

Satir, V., Banmen, J., Gerber, J., \& Gomori, M. (1991). The Satir Model. Science and Behavior Books.

Scales, P. C., \& Leffert, N. (2004). Developmental Assets: A Synthesis of the Scientific Research on Adolescent Development (2nd ed.). Search Institute Press.

Scheier, M. F., Wrosch, C., Baum, A., Cohen, S., Martire, L. M., Matthews, K. A. et al. (2006). The Life Engagement Test: Assessing Purpose in Life. Journal of Behavioral Medicine, 29, Article No. 291. https://doi.org/10.1007/s10865-005-9044-1

Scheiner, J., \& Sleater, A. M. (2020). Impact of the Therapist's “Use of Self”. The European Journal of Counselling Psychology, 8, 118-143.

https://doi.org/10.5964/ejcop.v8i1.160

Schippers, M. C., \& Ziegler, N. (2019). Life Crafting as a Way to Find Purpose and Meaning in Life. Frontiers in Psychology, 10, Article No. 2778.

https://doi.org/10.3389/fpsyg.2019.02778

Schlegel, R. J., Hicks, J. A., Arndt, J., \& King, L. A. (2009). Thine Own Self: True SelfConcept Accessibility and Meaning in Life. Journal of Personality and Social Psychology, 96, 473-490. https://doi.org/10.1037/a0014060

Schlegel, R. J., Vess, M., \& Arndt, J. (2012). To Discover or to Create: Metaphors and the True Self. Journal of Personality, 80, 969-993. 
https://doi.org/10.1111/j.1467-6494.2011.00753.x

Schneider, K. J. (2016). Existential-Integrative Therapy: Foundational Implications for Integrative Practice. Journal of Psychotherapy Integration, 26, 49-55. https://doi.org/10.1037/a0039632

Schneider, K. J., \& Krug, O. T. (2010). Theories of Psychotherapy. Existential-Humanistic Therapy. American Psychiatric Association. https://doi.org/10.1037/12050-003

Schneider, K. J., \& Leitner, L. M. (2002). Humanistic Psychotherapy. In M. Hersen, \& W. Sledge (Eds.), Encyclopedia of Psychotherapy (pp. 949-957). Academic Press

Schneider, K. J., \& May, R. (1995). The Psychology of Existence: An Integrative, Clinical Perspective. McGraw-Hill.

Schoeller, D. (2020). Authenticity as Emerging Meaning-Dialectics, Pragmatism, and Psychotherapy. In G. Brüntrup, M. Reder, \& L. Gierstl (Eds.), Authenticity (pp. 73-91). Springer VS. https://doi.org/10.1007/978-3-658-29661-2_5

Schulenberg, S. E., Schnetzer, L. W., \& Buchanan, E. M. (2011a). The Purpose in Life Test-Short Form: Development and Psychometric Support. Journal of Happiness Studies, 12, 861-876. https://doi.org/10.1007/s10902-010-9231-9

Schulenberg, S. E., Strack, K. M., \& Buchanan, E. M. (2011b). The Meaning in Life Questionnaire: Psychometric Properties with Individuals with Serious Mental Illness in AN Inpatient Setting. Journal of Clinical Psychology, 67, 1210-1219. https://doi.org/10.1002/jclp.20841

Sedikides, C., \& Skowronski, J. J. (1997). The Symbolic Self in Evolutionary Context. Personality and Social Psychology Review, 1, 80-102. https://doi.org/10.1207/s15327957pspr0101_6

Sheldon, K. M. (2004). Integrity (Honesty/Authenticity). In C. Peterson, \& M. E. P. Seligman (Eds.), Character Strengths and Virtues (pp. 249-272). Oxford University Press.

Sher, L. (2020). The Impact of the COVID-19 Pandemic on Suicide Rates. QJM: An International Journal of Medicine, 113, 707-712. https://doi.org/10.1093/qjmed/hcaa202

Shumaker, D. (2012). An Existential-Integrative Treatment of Anxious and Depressed Adolescents. Journal of Humanistic Psychology, 52, 375-400. https://doi.org/10.1177/0022167811422947

Siddique, S. (2011). Being In-Between: The Relevance of Ethnography and Auto-Ethnoaphy for Psychotherapy Research. Counselling and Psychotherapy Research, 11, 310-316. https://doi.org/10.1080/14733145.2010.533779

Smith, J. L. (2004). Food, Health and Psychology: Competing Recipes for Research and Understanding. Journal of Health Psychology, 9, 483-496.

https://doi.org/10.1177/1359105304044031

Snyder, C. R., Sympson, S. C., Ybasco, F. C., Borders, T. F., Babyak, M. A., \& Higgins, R. L. (1996). Development and Validation of the State Hope Scale. Journal of Personality and Social Psychology, 70, 321-335. https://doi.org/10.1037/0022-3514.70.2.321

Spinelli, E. (2006). The Value of Relatedness in Existential Psychotherapy and Phenomenological Enquiry. Indo-Pacific Journal of Phenomenology, 6, 1-8. https://doi.org/10.1080/20797222.2006.11433933

Spinelli, E. (2007). Practising Existential Psychotherapy: The Relational World. SAGE.

Stansfeld, S., \& Rasul, F. (2007). Psychosocial Factors, Depression and Illness. In A. Steptoe (Ed.), Depression and Physical Illness (p. 19-49). Cambridge University Press. https://doi.org/10.1017/CBO9780511544293.003

Steger, M. F. (2010). The MLQ Description, Scoring, and Feedback Packet. 
Steger, M. F. (2012). Experiencing Meaning in Life: Optimal Functioning at the Nexus of Well-Being, Psychopathology, and Spirituality. In P. T. P. Wong (Ed.), The Human Quest for Meaning (pp. 165-184).

Steger, M. F., Frazier, P., Oishi, S., \& Kaler, M. (2006). The Meaning in Life Questionnaire: Assessing the Presence of and Search for Meaning in Life. Journal of Counseling Psychology, 53, 80-93. https://doi.org/10.1037/0022-0167.53.1.80

Steger, M. F., Mann, J. R., Michels, P., \& Cooper, T. C. (2009a). Meaning in Life, Anxiety, Depression, and General Health among Smoking cessation patients. Journal of Psychosomatic Research, 67, 353-358. https://doi.org/10.1016/j.jpsychores.2009.02.006

Steger, M. F., Oishi, S., \& Kashdan, T. B. (2009b). Meaning in Life across the Life Span: Levels and Correlates of Meaning in Life from Emerging Adulthood to Older Adulthood. Journal of Positive Psychology, 4, 43-52.

https://doi.org/10.1080/17439760802303127

Stillman J. R. (2016). How Narrative Therapy Principles Inform Practice for Therapists and Helping Professionals: Illustrated with Vignettes. In V. Dickerson (Eds.), Poststructural and Narrative Thinking in Family Therapy (pp. 83-97). AFTA Springer Briefs in Family Therapy. Springer. https://doi.org/10.1007/978-3-319-31490-7_6

Stricker, G. (2003). The Many Faces of Self-Disclosure. Journal of Clinical Psychology, 59, 623-630. https://doi.org/10.1002/jclp.10165

Szasz, T. (2005). What Is Existential Therapy Not? Existential Analysis, 16, 127-130.

Tagini, A., \& Raffone, A. (2010). The 'I' and the 'Me' in Self-Referential Awareness: A Neurocognitive Hypothesis. Cognitive Processing, 11, 9-20. https://doi.org/10.1007/s10339-009-0336-1

Taylor, S. E. (1983). Adjustment to Threatening Events: A Theory of Cognitive Adaptation. American Psychologist, 38, 1161-1173. https://doi.org/10.1037/0003-066X.38.11.1161

Thapar, A., Collishaw, S., Potter, R., \& Thapar, A. K. (2010). Managing and Preventing Depression in Adolescents. BMJ, 340, Article No. c209. https://doi.org/10.1136/bmj.c209

Thompson, S. C., \& Janigian, A. S. (1988). Life Schemes: A Framework for Understanding the Search for Meaning. Journal of Social and Clinical Psychology, 7, 260-280.

Tillich, P. (1952). The Courage to Be. Yale University Press.

Tsang, S. K., Hui, E. K., \& Law, B. (2012). Positive Identity as a Positive Youth Development Construct: A Conceptual Review. The Scientific World Journal, 2012, Article ID: 529691. https://doi.org/10.1100/2012/529691

Twenge, J. M., Catanese, K. R., and Baumeister, R. F. (2003). Social Exclusion and the Deconstructed State: Time Perception, Meaninglessness, Lethargy, Lack of Emotion, and Self-Awareness. Journal of Personality and Social Psychology, 85, 409-423. https://doi.org/10.1037/0022-3514.85.3.409

Twenge, J. M., Cooper, A. B., Joiner, T. E., Duffy, M. E., \& Binau, S. G. (2019). Age, Period, and Cohort Trends in Mood Disorder Indicators and Suicide-Related Outcomes in a Nationally Representative Dataset, 2005-2017. Journal of Abnormal Psychology, 128, 185-199. https://doi.org/10.1037/abn0000410

Vallerand, R. J. (2008). On the Psychology of Passion: In Search of What Makes People's Lives Most Worth Living. Canadian Psychology, 49, 1-13. https://doi.org/10.1037/0708-5591.49.1.1

van Deurzen, E. (2012). Existential Counselling \& Psychotherapy in Practice. SAGE. van Inwagen, P. (1983). An Essay on Free Will. Oxford University Press. 
Vanhooren, S. (2019). Struggling with Meaninglessness: A Case Study from an Experiential-Existential Perspective. Person-Centered \& Experiential Psychotherapies, 18, 1-21. https://doi.org/10.1080/14779757.2019.1572029

Volkert, J., Schulz, H., Brütt, A. L., \& Andreas, S. (2014). Meaning in life: Relationship to Clinical Diagnosis and Psychotherapy Outcome. Journal of Clinical Psychology, 70, 528-535. https://doi.org/10.1002/jclp.22053

Wampold, B. E. (2012). Humanism as a Common Factor in Psychotherapy. Psychotherapy, 49, 445-449. https://doi.org/10.1037/a0027113

Wampold, B. E. (2015). How Important Are the Common Factors in Psychotherapy? An Update. World Psychiatry, 14, 270-277. https://doi.org/10.1002/wps.20238

Wampold, B. E. (2008). Existential-Integrative Psychotherapy: Coming of Age [Review of the Book Existential-Integrative Psychotherapy: Guideposts to the Core of Practice, by K. J. Schneider, Eds.]. PsycCRITIQUES, 53. https://psycnet.apa.org/record/2008-00279-001 https://doi.org/10.1037/a0011070

Wang, Y., Kala, M. P., \& Jafar, T. H. (2020). Factors Associated with Psychological Distress during the Coronavirus Disease 2019 (COVID-19) Pandemic on the Predominantly General Population: A Systematic Review and Meta-Analysis. PLoS ONE, 15, e0244630. https://doi.org/10.1371/journal.pone.0244630

Ward, A. (2019). Character and Discomfort. Character and ..., 5, 2-8. Wendt Center for Character Education, University of Dubuque.

Waterman, A. S. (1990). The Relevance of Aristotle's Conception of Eudaimonia for the Psychological Study of Happiness. Theoretical \& Philosophical Psychology, 10, 39-44. https://doi.org/10.1037/h0091489

Welling, H. (2005). The Intuitive Process: The Case of Psychotherapy. Journal of Psychotherapy Integration, 15, 19-47.

Whisman, M. A., \& Kwon, P. (1993). Life Stress and Dysphoria: The Role of Self-Esteem and Hopelessness. Journal of Personality and Social Psychology, 65, 1054-1060.

White, M. \& Epston, D. (1990). Narrative Means to Therapeutic Ends. W.W. Norton.

White, M. (1995). Re-Authoring Lives. Dulwich Centre Publications.

Williams, D. C., \& Levitt, H. M. (2007). Principles for Facilitating Agency in Psychotherapy. Psychotherapy Research, 17, 66-82.

https://doi.org/10.1080/10503300500469098

Winnicott, D. W. (1960). Ego Distortion in Terms of True and False Self. In The Maturational Process and the Facilitating Environment: Studies in the Theory of Emotional Development (pp. 140-152). International Universities Press.

https://doi.org/10.4324/9780429482410-12

Winnicott, D. W. (1965). The Maturational Processes and the Facilitating Environment: Studies in the Theory of Emotional Development. International Universities Press.

Winston, C. N. (2015). Points of Convergence and Divergence between Existential and Humanistic Psychology: A Few Observations. The Humanistic Psychologist, 43, 40-53. https://doi.org/10.1080/08873267.2014.993067

Wong, P. T. (1998). Implicit Theories of Meaningful Life and the Development of the Personal Meaning Profile. In P. T. P. Wong \& P. S. Fry (Eds.), The Human Quest for Meaning: A Handbook of Psychological Research and Clinical Applications (pp. 111-140). Lawrence Erlbaum. https://psycnet.apa.org/record/1998-06124-006

Wong, P. T. (2010). Meaning Therapy: An Integrative and Positive Existential Psychotherapy. Journal of Contemporary Psychotherapy, 40, 85-93. 


\section{https://doi.org/10.1007/s10879-009-9132-6}

Wong, P. T. (2011). Meaning-centered counseling and therapy: An integrative and comprehensive approach to motivational counseling and addiction treatment. In W. M. Cox, \& E. Klinger (Eds.), Handbook of motivational counseling: Goal-based approaches to assessment and intervention with addiction and other problems (pp. 461-487). John Wiley \& Sons. https://doi.org/10.1002/9780470979952.ch19

Wood, A. M., Linley, P. A., Maltby, J., Baliousis, M., \& Joseph, S. (2008). The Authentic Personality: A Theoretical and Empirical Conceptualization and the Development of the Authenticity Scale. Journal of Counseling Psychology, 55, 385-399. https://doi.org/10.1037/0022-0167.55.3.385

Woźniak, M. (2018). "I" and "Me": The Self in the Context of Consciousness. Frontiers in Psychology, 9, Article No. 1656. https://doi.org/10.3389/fpsyg.2018.01656

Yalom, I. D. (1980). Existential Psychotherapy. Harper Collins.

Yalom, I. D. (1991). Love's Executioner and Other Tales of Psychotherapy. Penguin.

Yalom, I. D. (2002). The Gift of Therapy: An Open Letter to a New Generation of Therapists and Their Patients. HarperCollins.

Yapko, M. (2009). Depression Is Contagious. How the Most Common Mood Disorder Is Spreading around the World and How to Stop It. Simon \& Schuster.

Zghoul, T., Cowen, P. J., \& Harmer, C. J. (2019). A Perspective: From the Serotonin Hypothesis to Cognitive Neuropsychological Approaches. In M. D. Tricklebank, \& E. Daly (Eds.), The Serotonin System (pp. 95-104). Academic Press. https://doi.org/10.1016/B978-0-12-813323-1.00005-0

Zika, S., \& Chamberlain, K. (1987). Relation of Hassles and Personality to Subjective Well-Being. Journal of Personality and Social Psychology, 53, 155-162. https://doi.org/10.1037/0022-3514.53.1.155

Ziv-Beiman, S. (2013). Therapist Self-Disclosure as an Integrative Intervention. Journal of Psychotherapy Integration, 23, 59-74. https://doi.org/10.1037/a0031783

Ziv-Beiman, S., \& Shahar, G. (2016). Therapeutic Self-Disclosure in Integrative Psychotherapy: When Is This a Clinical Error? Psychotherapy, 53, 273-277.

https://doi.org/10.1037/pst0000077 